\title{
INTEGRATION OF THE GPR AND RADIO-IMPEDANCE TECHNIQUES IN STUDIES OF THE BAIKAL RIFT ZONE
}

\author{
Yu. B. Bashkuev, V. B. Khaptanov, M. G. Dembelov \\ Institute of Physical Materials Science, Siberian Branch of RAS, Ulan-Ude, Russia
}

\begin{abstract}
Radio wave propagation techniques have been very rarely applied to investigate tectonic fault zones and geoelectric profiles of the Baikal rift zone. In our study, we used a combination of ground-penetrating radar (GPR) and radio impedance techniques in order to identify and investigate tectonic crustal fault zones in the study area. Using soundings in the super-long, long and ultra short radio wave ranges (from tens of $\mathrm{KHz}$ to few $\mathrm{GHz}$ ), we detected the tectonic fault zones in the seismically active Baikal rift zone, specifically in the Tunka depression and the areas of Southern Baikal and Kotokel lakes. Faults and fault zones were identified from impedance variations and changes in the geoelectric profiles by analyzing the radio impedance profiles and soundings in the super-long and long radio wave ranges. The georadiolocation of fault structures in the ultra-short wave range made it possible to differentiate the patterns of tectonic disturbances up to individual seismic dislocations in sedimentary and crystalline rocks and to determine the kinematics of movements in the fault zones. The techniques used in this study complement each other and ensure obtaining adequate quantitative descriptions of the study objects. By integrating various techniques of radio wave diagnostics, it is possible to obtain more detailed information on the structures of the tectonic fault zones. The results obtained in this study and the radio impedance and GPR sounding and profiling techniques developed to investigate a heterogeneous underlying medium can be used in seismological and geological engineering surveys of the eastern and northern regions of Russia.
\end{abstract}

Key words: radio impedance sounding; GPR; impedance; geoelectric profile; Baikal rift zone; tectonic zone; paleoseismodislocation

Статья публикуется по материалам доклада, сделанного авторами на XII Российско-Монгольской международной конференции «Солнечно-земные связи и геодинамика Байкало-Монгольского региона» (1-5 октября 2018 г., г. Иркутск)

For citation: Bashkuev Yu.B., Khaptanov V.B., Dembelov M.G., 2019. Integration of the GPR and radio-impedance techniques in studies of the Baikal rift zone. Geodynamics \& Tectonophysics 10 (3), 603-620. doi:10.5800/GT-2019-10-3-0429. 


\title{
КОМПЛЕКСИРОВАНИЕ ГЕОРАДАРНЫХ И РАДИОИМПЕДАНСНЫХ ЗОНДИРОВАНИЙ В БАЙКАЛЬСКОЙ РИФТОВОЙ ЗОНЕ
}

\author{
Ю. Б. Башкуев, В. Б. Хаптанов, М. Г. Дембелов \\ Институт физического материаловедения СО РАН, Улан-Удэ, Россия
}

\begin{abstract}
Аннотация: Актуальность работы определяется тем, что в пределах Байкальской рифтовой зоны целенаправленные исследования зон тектонических нарушений и их геоэлектрических разрезов радиоволновыми методами почти не проводились. Цель исследований - выявление и изучение зон тектонических нарушений земной коры в СДВ-ДВ и УКВ диапазонах радиоволн по данным измерений комплексом радиоволновых методов радиоимпедансного и георадарного зондирований. Рассмотрены результаты комплексирования СДВДВ и УКВ методов радиоволновой диагностики зон тектонических нарушений сейсмоактивной Байкальской рифтовой зоны в районах Тункинской впадины, Южного Байкала и озера Котокель в широком диапазоне радиоволн (от десятков килогерц до единиц гигагерц). Радиоимпедансное профилирование и зондирование в СДВ-ДВ диапазонах позволили обнаружить и локализовать разломы в земной коре по изменению импеданса и геоэлектрического разреза. Георадиолокация разломных структур в УКВ диапазоне сделала возможными дифференциацию тонкой структуры тектонического нарушения вплоть до отдельных сейсмодислокаций в осадочных и кристаллических породах и определение кинематики движений в разломной зоне. Использованные методы дополняют друг друга и позволяют количественно описать объект исследования. Комплексирование различных методов радиоволновой диагностики дает более подробную информацию о структуре зоны тектонических нарушений. Полученные результаты и разработанные методики радиоимпедансного и георадарного зондирования и профилирования неоднородной подстилающей среды могут быть использованы при сейсмологических и инженерно-геологических изысканиях в восточных и северных районах России.
\end{abstract}

Ключевые слова: радиоимпедансное зондирование; георадиолокация; импеданс; геоэлектрический разрез; Байкальская рифтовая зона; зона тектонических нарушений; палеосейсмодислокация

\section{1. ВВЕДЕНИЕ}

Район исследований относится к сейсмоактивной Байкальской рифтовой зоне (БРЗ). В связи с возрастающим интересом к методам электромагнитного мониторинга геодинамических процессов в сейсмоопасных районах Сибири представляется актуальным изучение зон тектонических нарушений БРЗ радиоволновыми методами.

Цель исследований - выявление и изучение зон тектонических нарушений (разломов) земной коры БРЗ в сверхдлинноволновом - длинноволновом (СДВ-ДВ) и УКВ диапазонах радиоволн по данным инструментальных радиофизических наблюдений радиоимпедансным и георадиолокационным (георадарным) методами.

Решаемые задачи:

- Радиоимпедансная диагностика зон тектонических нарушений в СДВ-ДВ диапазонах. Восстановление геоэлектрического разреза зон тектонических нарушений по измеренной частотной зависимости поверхностного импеданса.

- Георадарная диагностика зон тектонических нарушений на суше и в акваториях в УКВ диапазоне.
- Совместная интерпретация данных радиоимпедансного и георадарного зондирований при исследованиях зон тектонических нарушений.

Полевым отрядом ИФМ СО РАН в 2010-2018 гг. были проведены комплексные радиоэлектромагнитные зондирования для оценки современных геодинамических процессов в БРЗ.

\section{2. КРАТКИЙ ОБЗОР ПРОБЛЕМЫ}

Радиоволновые (электромагнитные) методы геофизики широко применяются при решении геологических и геодинамических задач, таких как картирование и выделение зон тектонических нарушений (разломов), определение геоэлектрического разреза (ГЭР) толщи кристаллических и осадочных горных пород, а также ряда других [Zherebtsov, 2012; Melchinov et al., 2006; Efremov, 2013; Tezkan, Saraev, 2008]. Однако в пределах БРЗ целенаправленных исследований зон тектонических нарушений и их ГЭР радиоволновыми методами почти не проводились [Bashkuev, 1996; Melchinov et al., 2006]. Большой объем радиоволновых измерений был выполнен при геоэлектрическом картировании востока Рос- 
сии и континентов земного шара для решения задач распространения радиоволн [Bashkuev et al., 2003]. При этом зоны тектонических нарушений из рассмотрения исключались. Радиоволновые зондирования в сверхнизкочастотном диапазоне электромагнитных волн (СНЧ, 30-300 Гц) выполнялись преимущественно с целью изучения глубинного строения региона в связи с поиском областей высокого удельного электрического сопротивления (УЭС) горных пород [Velikhov et al., 1998; Velikhov, 2014, 2015; Bashkuev, Khaptanov, 2009]. При этом приповерхностный ГЭР рассматривался как «обычный» элемент верхней части геологического разреза (ВЧР) без учета особенностей его электрических свойств, строения и связи с геотектоникой.

\section{3. МЕТОДЫ ИССЛЕДОВАНИЙ И ПРИЕМЫ АНАЛИЗА}

Измерения проведены комплексом радиоволновых методов радиоимпедансного и георадарного зондирований. По результатам СДВ-ДВ радиоимпедансного зондирования определены поверхностный импеданс и геоэлектрический разрез зон тектонических нарушений более чем в 100 пунктах зондирования. В районе исследований пройдено более 50 георадарных профилей общей протяженностью 30 км. Эти данные необходимы для создания электромагнитной модели разломов в земной коре БРЗ по локальным электрическим характеристикам подстилающей среды.

\section{1. РАДИОИМПЕДАНСНОЕ ЗОНДИРОВАНИЕ}

Электромагнитная задача получения количественных данных об электрических свойствах и геоэлектрическом разрезе зон тектонических нарушений БРЗ решалась на основе анализа амплитудно-фазовой структуры электромагнитного поля в точке наблюдения по данным метода радиоимпедансного зондирования в СДВ-ДВ диапазонах радиоволн [Bashkuev, 1996]. Метод основан на изучении амплитудно-фазовой структуры электромагнитного поля на границе раздела «воздух - подстилающая среда». Он позволяет производить непосредственные измерения модуля $(|\delta|)$ и фазы $\left(\varphi_{\delta}\right)$ поверхностного импеданса с использованием полей радиостанций. Физической основой метода является скин-эффект. По измеренным тангенциальным составляющим электрического $E_{\tau}$ и магнитного $H_{\tau}$ полей определяется приведенный поверхностный импеданс подстилающей среды:

$\delta=E_{\tau} / H_{\tau} \cdot Z_{0}$,

где $Z_{0}=\sqrt{\mu_{0} / \varepsilon_{0}}$ - характеристический импеданс свободного пространства, $\mu_{0}$ - магнитная проница- емость вакуума, $\varepsilon_{0}$ - диэлектрическая проницаемость вакуума. По своей физической основе радиоимпедансный метод очень близок к методу магнитотеллурического зондирования (МТ3). Только вместо естественного источника зондирующего электромагнитного поля используются искусственные поля СНЧ-СДВ-ДВ-СВ радиостанций. При падении плоской вертикально поляризованной волны на плоскую поверхность однородной изотропной и немагнитной среды имеет место соотношение:

$\delta=\sqrt{\varepsilon_{k}-\sin ^{2} \theta} / \varepsilon_{k}$

где $\varepsilon_{k}=\varepsilon+i 60 \lambda \sigma$ - относительная комплексная диэлектрическая проницаемость среды; $\theta$ - угол падения волны. Для слоистой плоскопараллельной среды $\delta=\delta_{1} \cdot \mathrm{Q}^{(\mathrm{n})}$, где $\delta_{1}$ - приведенный поверхностный импеданс первого слоя; $\mathrm{Q}^{(\mathrm{n})}=$ $=f\left(\omega, \theta, \varepsilon_{i}, \sigma_{i}, h_{i}\right)$ - корректирующий множитель, учитывающий влияние нижележащих слоев. Поверхностный импеданс зависит от электрических параметров слоев $\sigma_{i}, \varepsilon_{i}$, толщины слоев $h_{i}$ и частоты поля $\omega$ и не зависит от мощности излучения радиопередатчика и расстояния до него, а также от угла падения волны $\theta$ при $\left|\varepsilon_{k}\right| \gg 1$. Глубина проникновения электромагнитного поля (скин-слой) определяется соотношением $h=\sqrt{2 /\left(\omega \mu_{0} \sigma\right)}$ и зависит от частоты $\omega$ и проводимости среды $\sigma$. Следовательно, изменяя частоту $\omega$, можно изменять глубину проникновения в среду и получать сведения об электрических свойствах геологической структуры на различных глубинах. В этом и состоит принцип радиоинтроскопии подстилающей среды (горного массива или акватории). Слой скинэффекта при $\sigma=10^{-4} \mathrm{~cm} /$ м составляет 50 м на частоте 1 МГц. Для измерений использованы поля СДВ-ДВ радиостанций 22.2; 50; 180 и 279 кГц. Импедансметр представляет собой селективный микровольтметр-фазометр, измеряющий частотную зависимость модуля и фазы поверхностного импеданса, по которым при решении обратной задачи для модели слоистой среды определяются параметры ГЭР - проводимость $\sigma_{i}$, диэлектрическая проницаемость $\varepsilon_{i}$ и мощность $h_{i}$ каждого $i$-го слоя [Melchinov et al., 2006]. При измерениях использовался портативный импедансметр ИПИ-300, обеспечивающий определение модуля импеданса с погрешностью \pm 5 \%, фазы импеданса $\pm(1-2)^{\circ}$. Для измерений тангенциальной составляющей электрического поля $E_{\tau}$ применялась симметричная незаземленная приемная линия длиной 20 м, позволяющая работать как на высокопроводящих, так и на плохопроводящих ГЭР. Датчиком тангенциальной составляющей магнитного поля $H_{\tau}$ служила рамочная антенна с блоком симметрирования. 
Yu.B. Bashkuev et al.: Integration of the GPR and radio-impedance techniques...

Пункт наблюдения
Дата
$\begin{aligned} & \text { Время } \\ & \text { Координаты З.н Змеевая }\end{aligned}$

\begin{tabular}{|c|c|c|c|c|c|c|c|c|}
\hline f, кГц & $\begin{array}{c}\text { пеленг, } \\
\text { град }\end{array}$ & $A, d B$ & $\varphi,{ }^{\circ}$ & f, кГц & $|\delta|$ & $\varphi_{\delta},{ }^{\circ}$ & $\begin{array}{l}\rho_{\text {эф, }} \\
\text { OM.M }\end{array}$ & $h_{c c}, M$ \\
\hline 22.2 & 22.2 & 24.4 & 50 & 22.2 & 0.015 & -50 & 186 & 115 \\
\hline 50 & 50 & 20.7 & 56 & 50 & 0.024 & -54.3 & 209 & 81 \\
\hline 180 & 180 & 26.6 & 50 & 180 & 0.048 & -47.5 & 234 & 45 \\
\hline 234 & 50 & 28.9 & 49 & 234 & 0.061 & -47 & 282 & 43 \\
\hline 279 & 50 & 30 & 47 & 279 & 0.068 & -45.7 & 302 & 41 \\
\hline
\end{tabular}

\begin{tabular}{|c|c|c|}
\multicolumn{3}{|c}{ Решение } \\
\hline$\varepsilon$ & $\rho$ & $\mathrm{h}$ \\
\hline 10 & 269 & 16 \\
\hline 10 & 132 & 41 \\
\hline 10 & 497 & \\
\hline
\end{tabular}
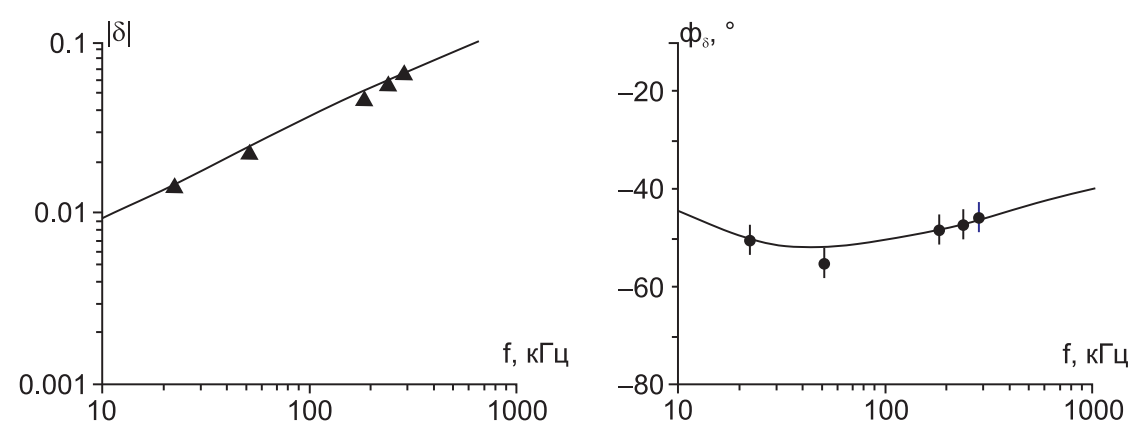

Рис. 1. Результаты интерпретации модуля и фазы импеданса, измеренных на пяти частотах СДВ-ДВ диапазонов в бухте Змеевой. Сплошные линии - зависимости импеданса для восстановленного разреза, точки - экспериментальные значения импеданса.

Fig. 1. Interpretation of the impedance modulus and phase measured at five frequencies of the super-long and long radio wave ranges in the Zmeevaya Bay. Solid lines - impedance dependences for the reconstructed profile; dots - impedance values in the experiments.

Для решения обратной задачи радиоимпедансного зондирования для слоистой полупроводящей среды, удовлетворяющей импедансным граничным условиям, разработан алгоритм метода регуляризации на основе гипотетического разреза [Angarkhayeva, 2002]. Сглаживающий функционал А.Н. Тихонова имеет вид:

$$
M_{\alpha}[\mathrm{g}]=I[\mathrm{~g}]+\alpha \Omega[\mathrm{g}]
$$

где $I[\mathrm{~g}]=\sum_{l=1}^{L}\left|\delta_{l}-\delta_{l_{9}}\right|^{2}-$ функционал невязки; $\Omega[\mathrm{g}]=\sum_{n=1}^{N} p_{n}\left|\varepsilon_{n}-\varepsilon_{n}^{0}\right|^{2}+\sum_{n=1}^{N} q_{n}\left|\sigma_{n}-\sigma_{n}^{0}\right|^{2}+$ $+\sum_{n=1}^{N-1} r_{n}\left|h_{n}-h_{n}^{0}\right|^{2}$ - стабилизирующий функционал; $\mathrm{g}=(\varepsilon, \sigma, h)$ - параметры многослойной полупроводящей среды; $\alpha$ - параметр регуляризации; $\left(\varepsilon^{0}, \sigma^{0}, h^{0}\right)$ - гипотетическое распределение параметров разреза; $p_{n}, q_{n}, r_{n}$ - веса соответствующих параметров; $\delta_{l_{\ni}}$ - экспериментальные значения импеданса на $l$-ой частоте. Минимизация рассматри- ваемого функционала производилась с помощью метода Ньютона-Канторовича (метода линеаризации). Критерием выбора «наилучшего» геоэлектрического разреза служит минимум среднеквадратического отклонения экспериментальных значений импеданса от рассчитанных для модели $n$-слойной среды. При решении обратной задачи частотная дисперсия электрических свойств горных пород в диапазоне 22-279 кГц не учитывалась. На рис. 1 представлен пример интерпретации данных радиоимпедансного зондирования в бухте Змеевой.

\section{2. ГЕОРАДАРНОЕ ЗОНДИРОВАНИЕ}

Принцип действия аппаратуры подповерхностного радиолокационного зондирования (георадара) основан на излучении широкополосных (наносекундных) импульсов метрового и дециметрового 


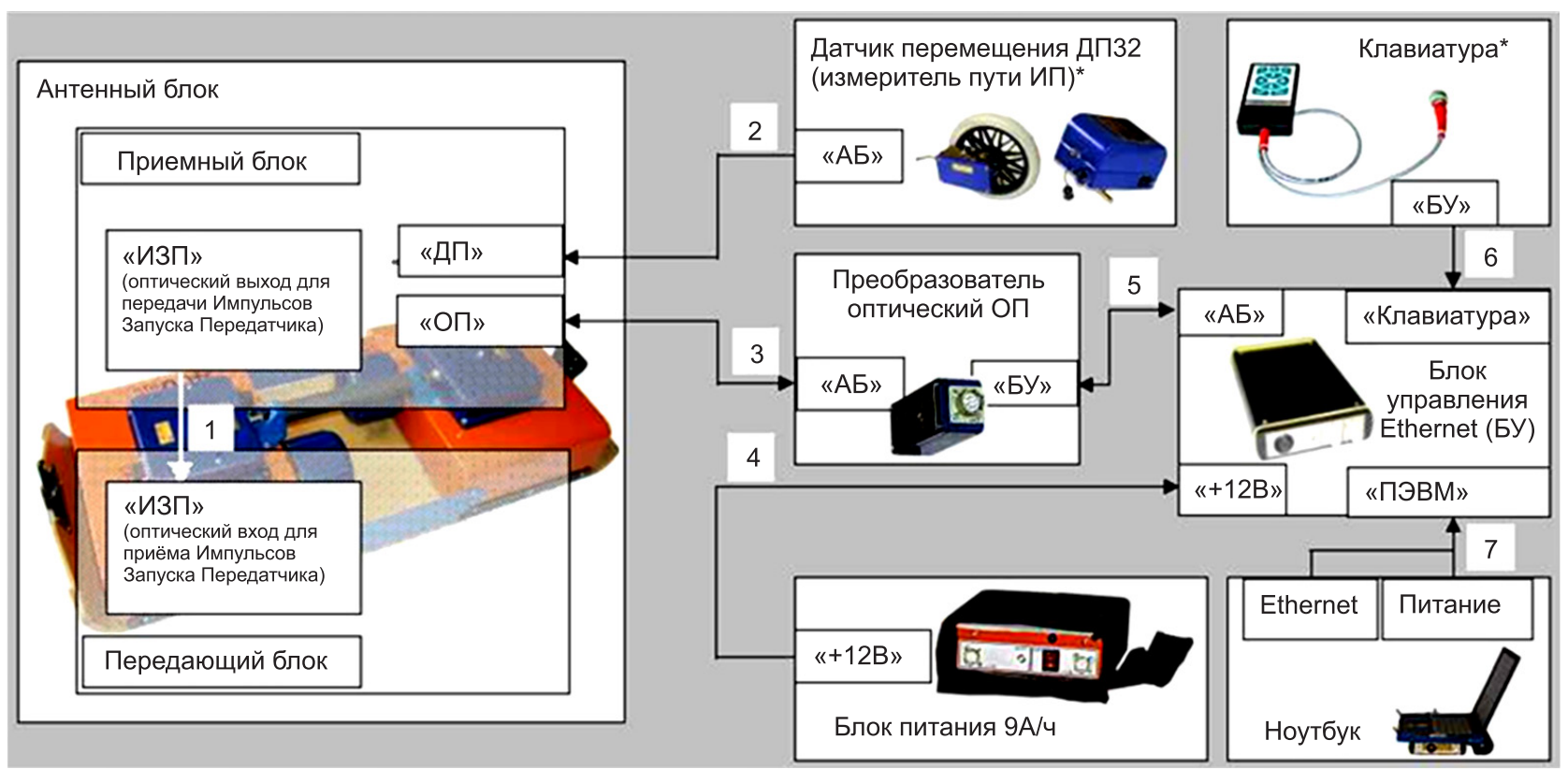

Рис. 2. Функциональная схема георадара Око-2 с ПЭВМ.

Fig.2. Functional arrangements of an Oko-2 georadar and a PC.

диапазона электромагнитных волн и приеме сигналов, отраженных от границ раздела слоев зондируемой среды, имеющих различные электрофизические свойства. Для георадиолокации использовался радиотехнический прибор подповерхностного зондирования (георадар) «Око-2» с антенными блоками АБДЛ «Тритон» и АБ-400 с центральными частотами 50 и 400 МГц [Radio Engineering Device..., 2006; Vladov, Starovoitov, 2004; Semeikin et al., 2005] (рис. 2). Глубина зондирования георадара «Око-2» зависит от мощности его излучателя (передатчика), чувствительности его приемника и, наиболее существенно, от электрофизических свойств грунта - удельного электрического сопротивления $\rho$ (УЭС) и диэлектрической проницаемости $\varepsilon$, определяющих скин-слой. Для пород с высоким УЭС (500-10000 Ом·м), характерных для горных районов, реальная глубина зондирования увеличивается по сравнению с расчетной глубиной, приведенной в технических описаниях, до 30-50 \%. Так, для АБДЛ «Тритон» она достигает 30 м при разрешающей способности по глубине $0.5 \mathrm{M}$, а для блока АБ-400 - достигает 5-7 м при разрешающей способности по глубине 0.15 м. При съемке георадар перемещался вдоль заданного профиля длиной от 0.05 до 9.00 км. При перемещении георадара по профилю исследуемого участка на экран монитора выводится совокупность сигналов (радарограмма), по которой определяется слоистость среды, местонахождение, глубина залегания и протяженность объектов (как проводящих (металлических), так и диэлектрических) [GeoScan32, 2013].

\section{4. РЕЗУЛЬТАТЫ ИЗМЕРЕНИЙ ПОВЕРХНОСТНОГО ИМПЕДАНСА И ГЕОРАДАРНЫЕ РАЗРЕЗЫ РАЗЛОМНЫХ СТРУКТУР В ЗЕМНОЙ КОРЕ}

Палеосейсмодислокации - своеобразные формы рельефа, образующиеся в эпицентрах сильных землетрясений, происходивших сотни и тысячи лет назад. Их изучение позволяет уверенно определять районы землетрясений, объективно оценивать их мощность и глубину, проводить сейсмическое районирование территории и решать ряд других актуальных проблем, связанных с прогнозом сейсмической опасности.

Пункты наблюдения располагались в Тункинской впадине (районы с. Торы (Далахай), п. Кырен и п. Култук), в отрогах Баргузинского хребта, на побережье оз. Байкал и на оз. Котокель. Измерения поверхностного импеданса проведены на частотах СДВ (22.2 кГц), ДВ (50, 279 кГц) диапазонов в более 100 пунктах наблюдений.

\section{1. ТУНКИНСКАЯ ВПАДИНА}

С целью определения кинематики движений блоков земной коры при сильных землетрясениях в пределах северного и южного обрамлений Тункинской впадины БРЗ методами георадарного и радиоимпедансного зондирования исследованы зоны Торской и Кыренской палеосейсмодислокаций [Zherebtsov, 2012]. В Тункинской впадине проведена количественная интерпретация слоисто- 


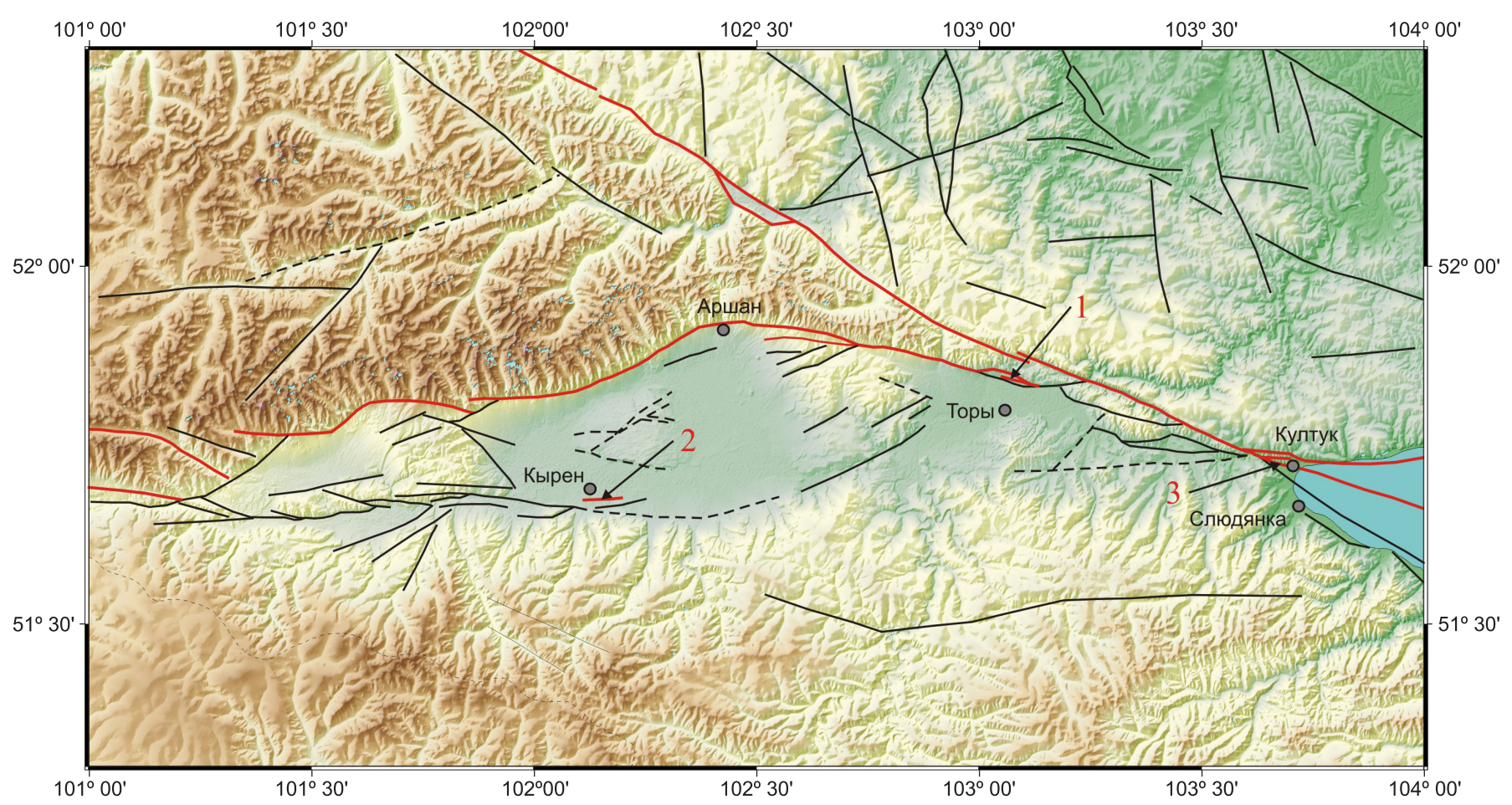

Рис. 3. Карта зон тектонических нарушений (сейсмодислокаций) Тункинской впадины с пунктами измерений: 1 - Торы (Далахай), 2 - Кырен, 3 - Култук. Цифры в квадратах - номера пунктов радиоимпедансных зондирований.

Fig. 3. Map of the Tunkia depression showing the zones of tectonic disturbances (seismic dislocations) and measurement points: 1 - Tory (Dalakhai), 2 - Kyren, 3 - Kultuk. Numbers in boxes - numbers of radio impedance sounding points.

неоднородной среды в СДВ-ДВ и УКВ диапазонах на глубину до 100 м. На рис. 3 представлен план района исследований с нанесенными пунктами измерений поверхностного импеданса и георадарного зондирования.

Торская палеосейсмодислокация. Торская палесейсмодислокация представлена западно-северозападным (3С3) уступом, заложившимся по сейсмо- генному разлому, ограничивающему с юга Уланнурскую плоскодонную котловину [Smekalin, 2008]. Высота уступа составляет 1.0-2.0 м (рис. 4).

На радарограммах зона тектонического разлома в крест простирания Торской палеосейсмодислокации (ПСС) представлена слоистой толщей с коленообразным изгибом слоев горных пород в вертикальном направлении (флексура) с разрывами

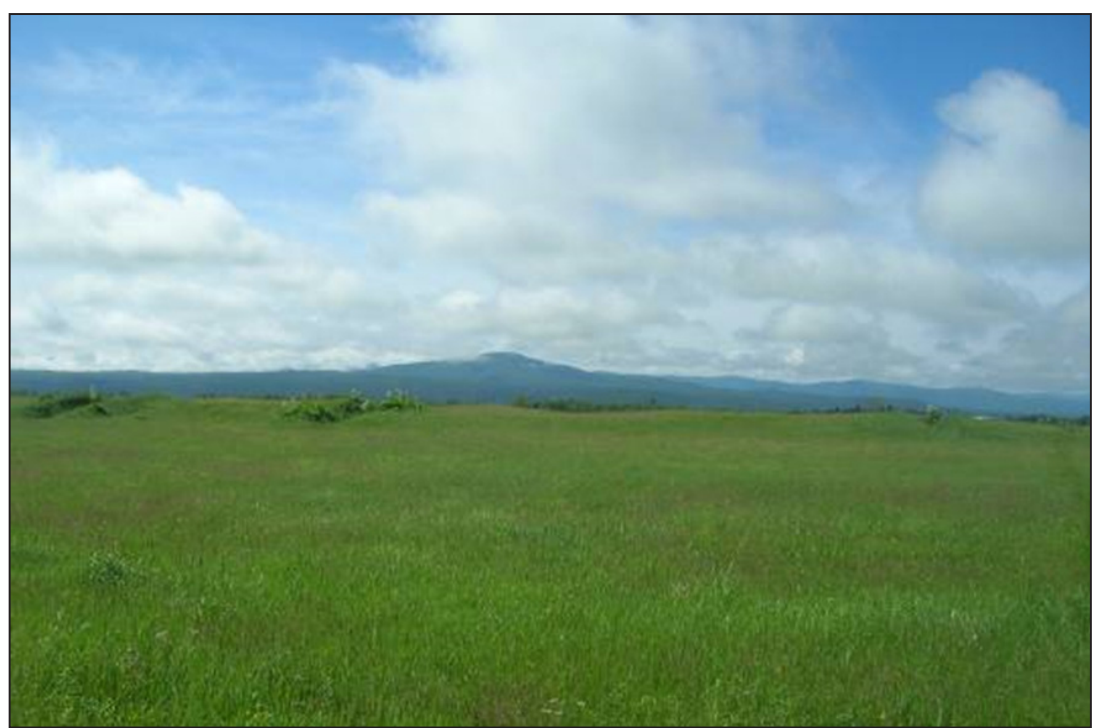

Рис. 4. ЗСЗ уступ Торской палеосейсмодислокации в районе с. Далахай.

Fig. 4. The western-north-western ledge of the Tora paleoseismic dislocation near the Dalahay village. 
(a)

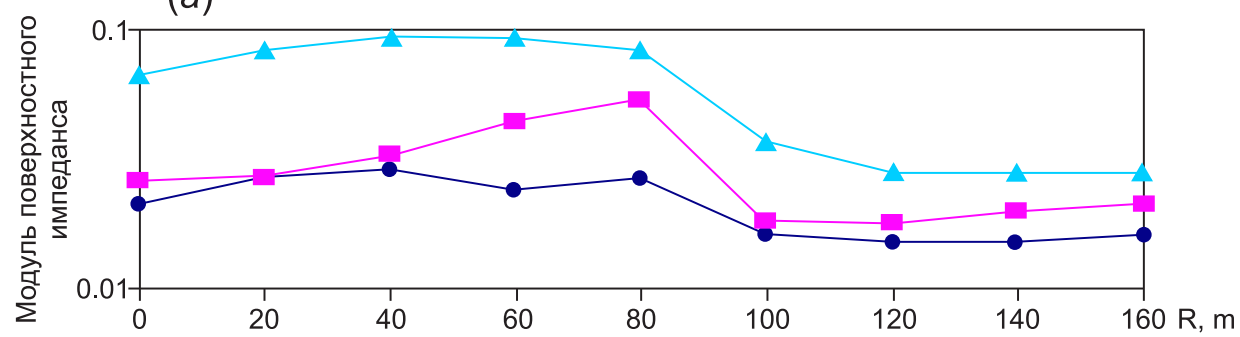

(6)

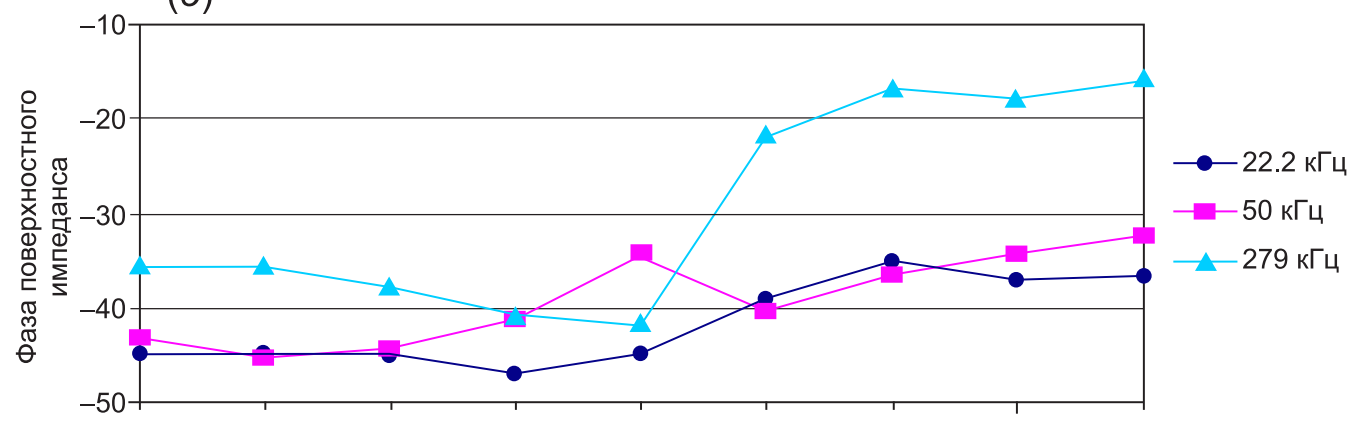

(8)

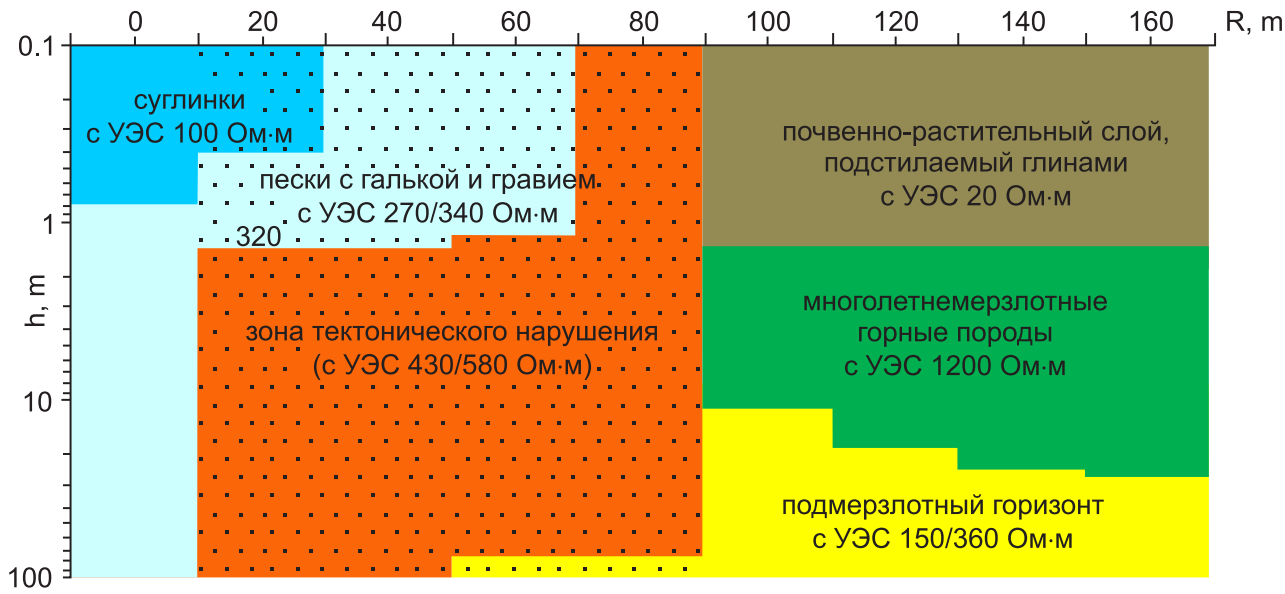

(2)

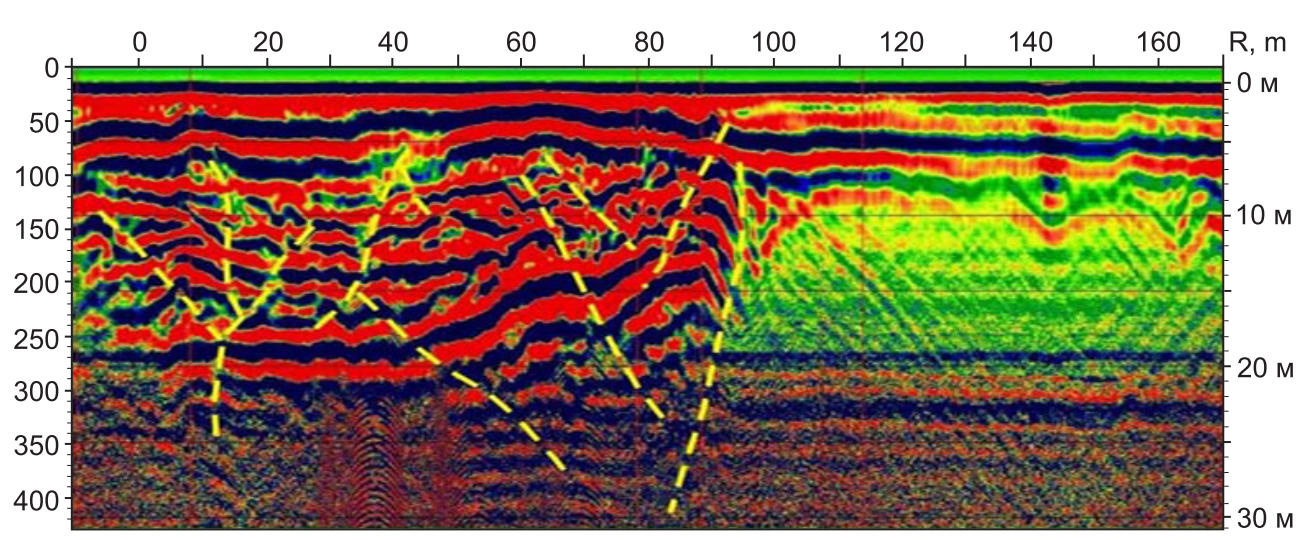

Рис. 5. Результаты радиоимпедансного зондирования на профиле в крест простирания Торской палеосейсмодислокации: (a) и (б) - модуль и фаза импеданса на частотах 22.2, 50 и 279 кГц; (в) - геоэлектрический разрез, зона тектонического нарушения выделена крапом; (2) - радарограмма зоны разлома. Георадар «0ко-2», антенный блок АБДЛ «Тритон» (50 МГц). Вверху черной кривой показано положение уступа, выраженное в рельефе. Желтые линии - предполагаемые разломы в осадочных отложениях.

Fig. 5. Radio impedance sounding data on the profile across the strike of the Tora paleoseismic dislocation: (a) and (б) - impedance modulus and phase at sounding frequencies of $22.2,50$ and $279 \mathrm{kHz} ;(8)-$ geoelectrical profile (the tectonic fault zone is dotted); (2) radarogram of the fault zone. Oko-2 georadar. ABDL Triton antenna block (50 MHz). Black curve at the top - position of the ledge expressed in relief. Yellow lines - assumed faults in sediments.

сбросовой и взбросовой кинематики (рис. 5, г). На глубине более 10 м разрывы имеют субвертикальное падение или образуют «пальмовые» структуры. В верхней части разреза в зоне уступа отмечаются сбросы, выкручивающиеся с глубиной. Сочетание складчатых и разрывных деформаций, на- блюдаемое в разрезах, и геоморфологические данные о выраженности разрыва на поверхности указывают на поднятие южного блока с левосторонним сдвигом. Радарограмма показывает резкую границу смены состояния массива горных пород после уступа (зеленый цвет на радарограмме). 


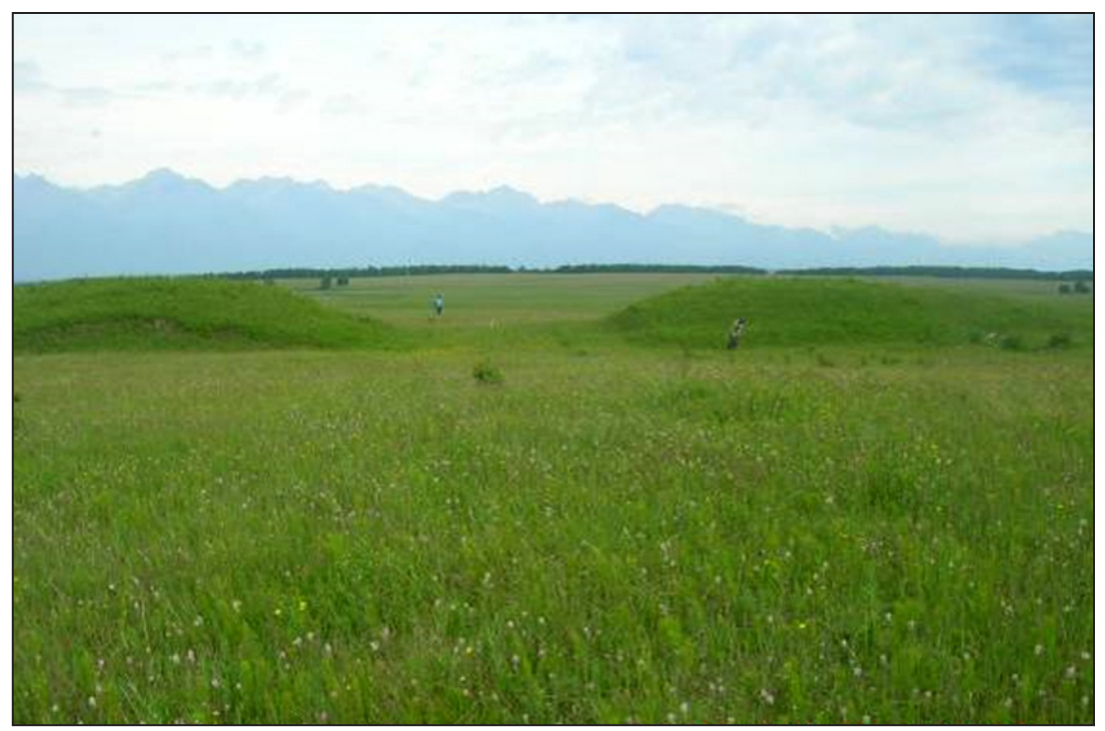

Рис. 6. Бугры смятия в зоне Кыренской сейсмодислокации.

Fig. 6. Mounds in the Kyren seismic dislocation zone.

Радиоимпедансные зондирования на частотах 22.2, 50 и 279 кГц на профиле длиной 180 м в этом же пункте (рис. 5, $a-8$ ) показали резкую смену типа геоэлектрического разреза, проявившуюся в слабоиндуктивном характере поверхностного импеданса (фаза импеданса достигает $-16^{\circ}$ ) на частоте 279 кГц. В результате интерпретации частотных зависимостей поверхностного импеданса на девяти пикетах профиля установлено наличие слоя многолетней мерзлоты в предгорной части профиля [Zherebtsov, 2012].

Кыренская палеосейсмодислокащия. Объект исследования располагается на южном склоне Тункинской впадины, в районе п. Кырен, в междуречье рек Кырен, Харбяты, вдоль субширотного уступа простирания $100^{\circ}$ и высотой от 1 до 2.5 м. На его протяжении фиксируются левосторонние смещения долин временных водотоков с амплитудой 1314 м. Верхняя часть уступа осложнена антиклинальными складками, которые в рельефе выражены буграми длиной 10-20 м и высотой около 2 м (рис. 6).

На радарограмме (рис. 7) структура разреза представлена зоной разрывных и складчатых деформаций, прослеживающихся как минимум до глубины 25 м. Разрывы имеют как взбросовую, так и сбросовую кинематику, падение, по большей части, в сторону оси зоны. В верхней части разреза

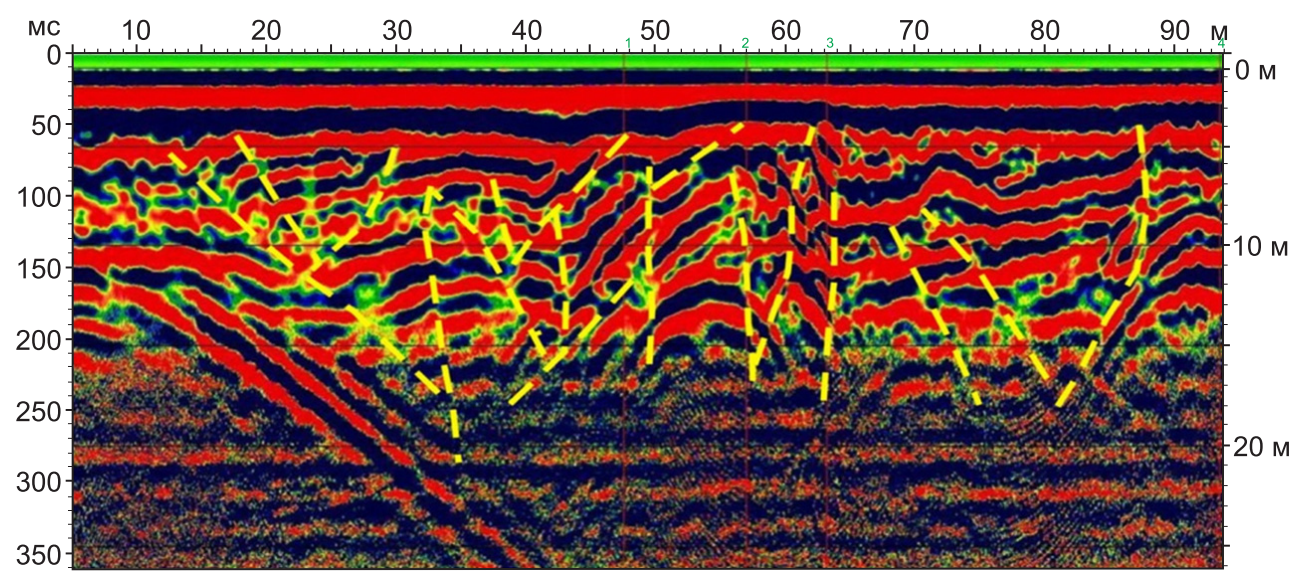

Рис. 7. Радарограмма субмеридиональной зоны тектонического разлома в крест простирания палеосейсмодислокации «Кырен». Границы и вершина выраженного в рельефе вала показаны метками 1, 2, 3. Желтые линии - предполагаемые разломы в осадочных отложениях. Георадар «ОКО-2», антенный блок АБДЛ «Тритон».

Fig. 7. Radarogram of the submeridional tectonic fault zone across of the strike of the Kyren paleoseismic dislocation. Marks $1,2,3$ - boundaries and the top of the earth mound expressed in relief. Yellow lines - assumed faults in sediments. Oko- 2 georadar. ABDL Triton antenna block. 
отчетливо выделяется асимметричный выпуклый изгиб (антиклиналь) с пологим южным и крутым северным крылом, ограниченный с севера зоной крутопадающих разрывов взбросовой и сбросовой кинематики. Такое сочетание складчатых и разрывных деформаций с типичной «пальмовой» структурой характерно для сдвиговых зон. Таким образом, ПСС «Кырен» возникла в результате левосторонних сдвиго-взбросовых движений по ЮжноТункинскому разлому.

По данным радиоимпедансного зондирования зона тектонического нарушения в геоэлектрическом разрезе отчетливо не выделяется (рис. 8). Она имеет лишь немного большие удельные сопротивления.

Метод радиоимпедансного зондирования имеет ограничения по пространственному разрешению узких зон разломов. Он хорошо выделяет разломы шириной в десятки и сотни метров. На рис. 9 представлен профиль радиоимпедансных зондирований поперек разлома шириной 80 м в предгорной части Баргузинского хребта. Разломная зона выражена на профиле длиной 220 м характерным понижением модуля импеданса, связанным с существенным понижением удельного сопротивления.

Комплексная интерпретация данных георадарного и радиоимпедансного зондирования позволила надежно определить ширину зон деформации и глубину их погружения с учетом рельефа дневной поверхности, а также сделать некоторые заключения о кинематике (сброс, сдвиг и т.д.) тектонических нарушений.

\section{2. ОЗЕРО БАЙКАЛ (РАЙОН ПОС. КУЛТУК)}

С целью поиска разломных структур под дном оз. Байкал в марте 2013 г. полевым отрядом ИФМ СО РАН совместно с ИЗК СО РАН проведены измерения на трех профилях в южной части озера (район пос. Култук) методами радиоимпедансного и георадарного зондирования. Схема расположения профилей приведена на рис. 10. В качестве примера приведем результат интерпретации радиоимпедансного зондирования на пикете 2 профиля № 2, на котором по частотной зависимости поверхностного импеданса получен 4-слойный геоэлектрический разрез со следующими параметрами:

$\begin{array}{lll}\varepsilon_{1}=5, & \rho_{1}=501 \mathrm{OM} \cdot \mathrm{M}, & h_{1}=1.8 \mathrm{M} ; \\ \varepsilon_{2}=10, & \rho_{2}=155 \mathrm{OM} \cdot \mathrm{M}, & h_{2}=1.7 \mathrm{M} ; \\ \varepsilon_{3}=10, & \rho_{3}=35 \mathrm{OM} \cdot \mathrm{M}, & h_{3}=1.0 \mathrm{M} ; \\ \varepsilon_{4}=10, & \rho_{4}=112 \mathrm{OM} \cdot \mathrm{M}, & h_{4}=\infty .\end{array}$

Профиль 1. На рис. 11 представлены радарограммы, полученные с помощью антенных блоков «Тритон» $(a)$ и АБ-400 (б) на профиле 1. Профиль начинается от насыпи Кругобайкальской железной дороги в 24 м от берега и продолжается по льду озера на протяжении 252 м. Максимальная глубина зондирования озера для АБДЛ «Тритон» составила 14 м и ограничена, несмотря на хорошее отражение от дна, длительностью развертки георадара (800 нс). Для антенного блока АБ-400 максимальная глубина зондирования составила 6 м и ограничена не только длительностью развертки георадара с АБ-400 (350 нс), но и ослаблением сигнала в байкальской воде с удельным электрическим сопротивлением (УЭС) 150 Ом·м. Крутизна подводного склона Байкала в этом месте существенно увеличивается с удалением от берега и имеет неоднородности, связанные с его тектоническим происхождением (рис. $11, a)$.

На рис. 12 крупным планом представлена радарограмма начала профиля 1 с выходом на ледовую поверхность Байкала с диэлектрической проницаемостью льда $\varepsilon_{\text {лед}}=3.14$. Толщина ледового покрова колеблется в пределах 0.75-0.85 м в зависимости от толщины снежного покрова. Из-за слабого затухания сигнала во льду наблюдаются сильные по амплитуде кратные волны под ледовым покровом. Прослеживается подошва мерзлого грунта до глубины 2.0-2.5 м. В толще мерзлого грунта есть элементы дислокаций (линии нарушений согласного залегания слоев и разрушенность структуры грунта).

Профиль 2. Профиль проходит в 100 м от береговой линии Байкала, пересекая подъездную дорогу к заброшенному нефтеналивному пирсу. Радарограммы профиля представлены на рис. 13. На протяжении 70 м профиль проложен по насыпной дороге, соединяющей нефтеналивной пирс с угольным причалом. Остальная часть профиля проходит по заболоченному участку с глубоким снежным покровом, что ограничило длину профиля 170 м с АБ400 и 140 м с АБДЛ «Тритон». Более светлые области радарограмм свидетельствуют о более сильном ослаблении зондирующего сигнала. Прослеживается подошва мерзлого грунта: до конца насыпной дороги на глубине 2 м, в переходной зоне 72-90 м на глубине $\sim 1.3$ м и $\sim 2$ м на второй половине радарограммы (рис. 13, a). Существенные различия в глубине промерзания обусловлены разницей в толщине снежного покрова от 0 м на полотне дороги и более 0.5 м на заболоченном участке. В основании дорожной насыпи на глубине 1.8 м, судя по имеющимся гиперболам, много камней. Наличие выраженных сейсмодислокаций на всем протяжении профиля свидетельствует о том, что не вся зона разлома охвачена обследованием (рис. 13).

Профиль 3. Профиль длиной 350 м находится на мелководье в 0.5 км от устья реки, протекающей через п. Култук. На радарограмме с АБ-400 видна 
(a)

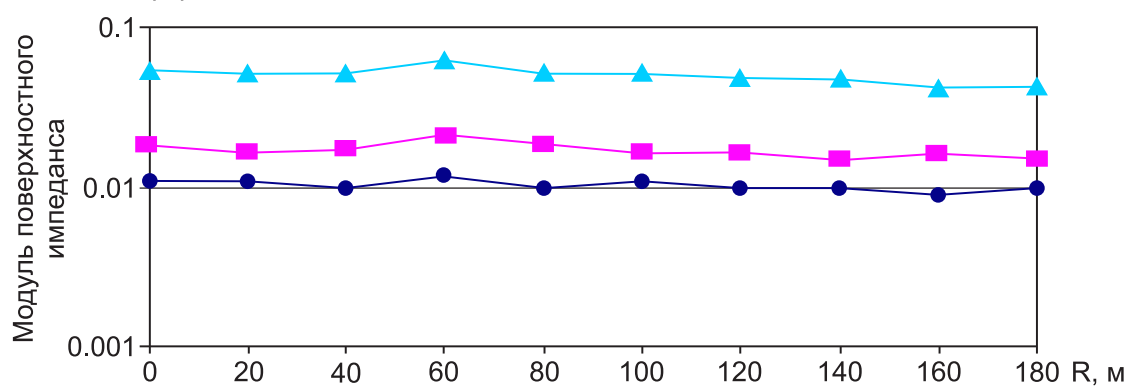

(б)

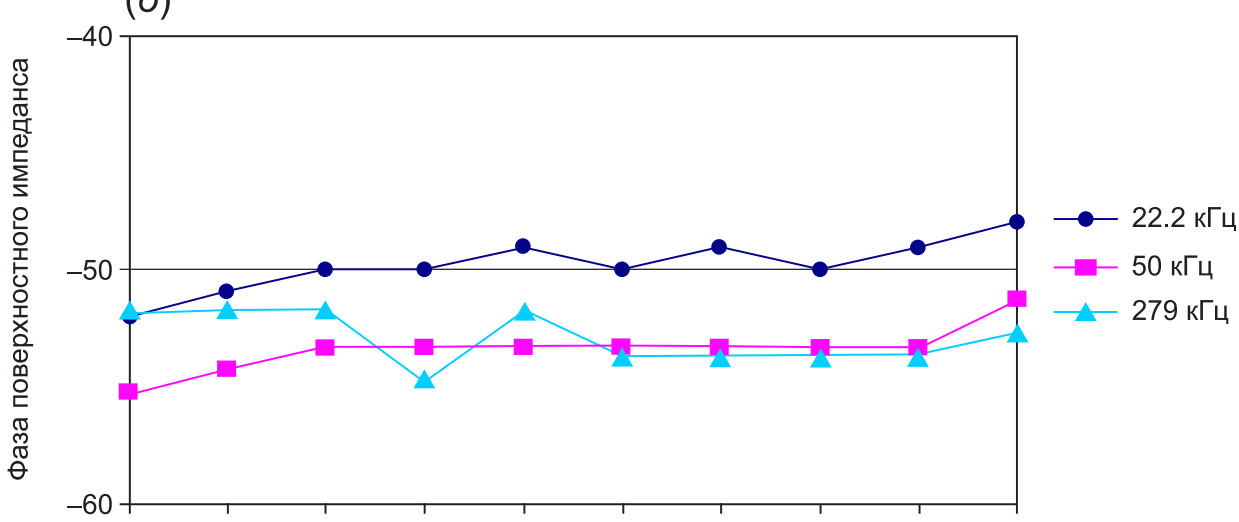

(в)

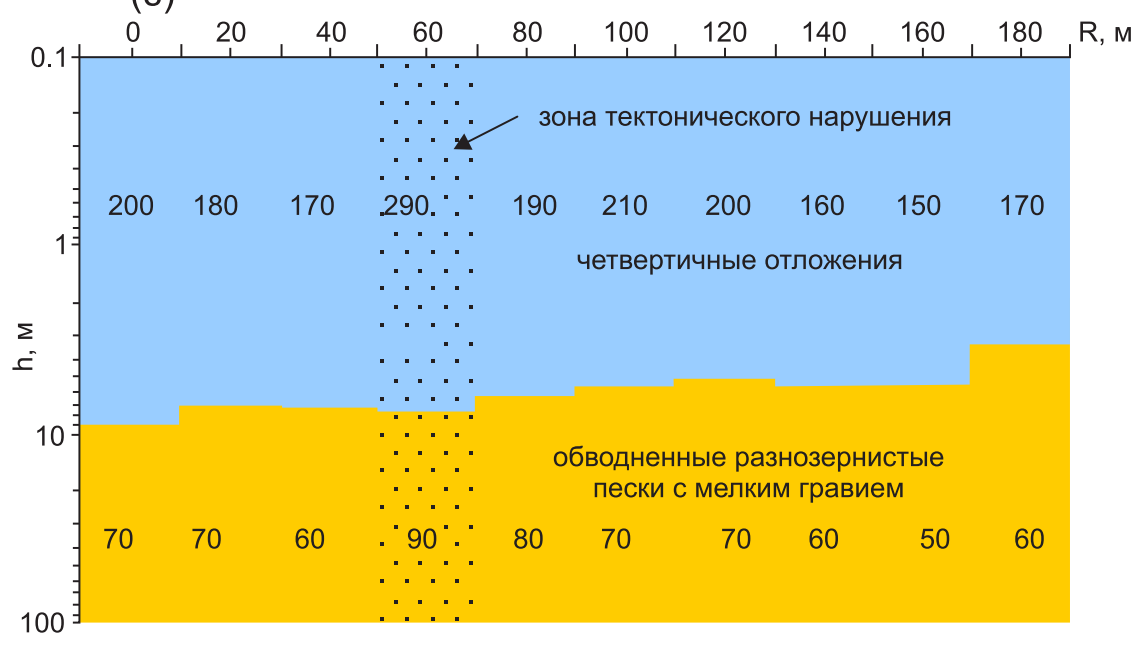

Рис. 8. Результаты радиоимпедансного зондирования на профиле «Кырен» в зоне тектонического разлома (сейсмодислокации) Тункинской впадины: (a) и (б) - модуль и фаза импеданса на частотах зондирования $22.2,50$ и 279 кГц; (в) - геоэлектрический разрез. Зона тектонического нарушения выделена крапом.

Fig. 8. Radio impedance sounding data on the Kyren profile in the tectonic fault zone (seismic dislocation) of the Tunka depression: $(a)$ and (6) - impedance modulus and phase at sounding frequencies of $22.2,50$ and $279 \mathrm{kHz} ;(\theta)$ - geoelectrical profile. The tectonic fault zone is dotted.
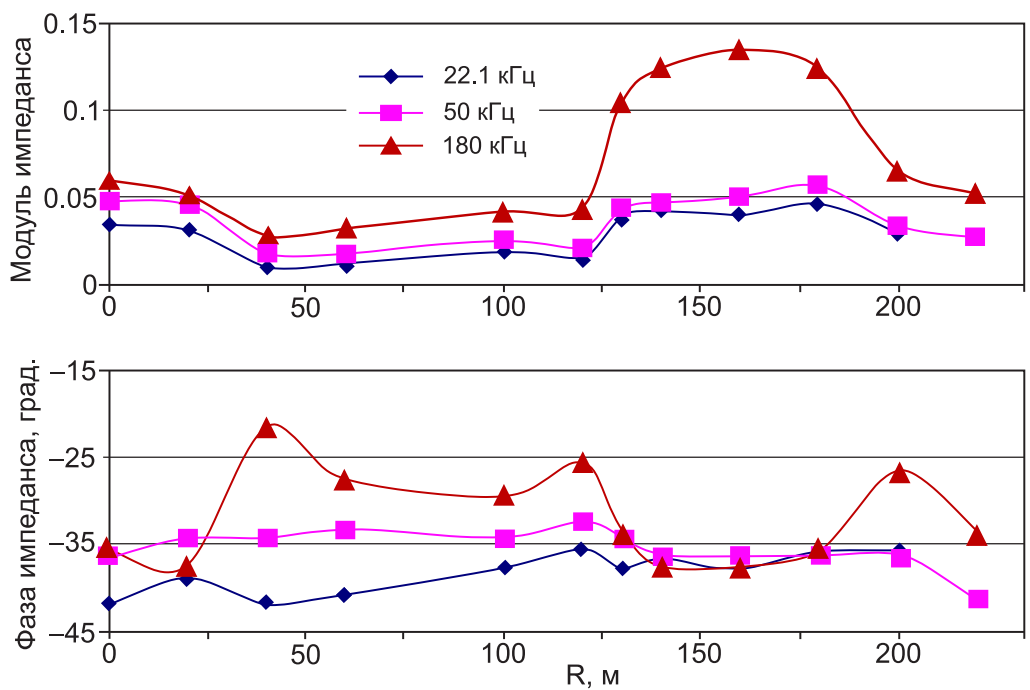

Рис. 9. Профиль радиоимпедансных зондирований в предгорной зоне Баргузинского хребта.

Fig. 9. Radio impedance sounding profile for the piedmont zone of the Barguzin ridge. 


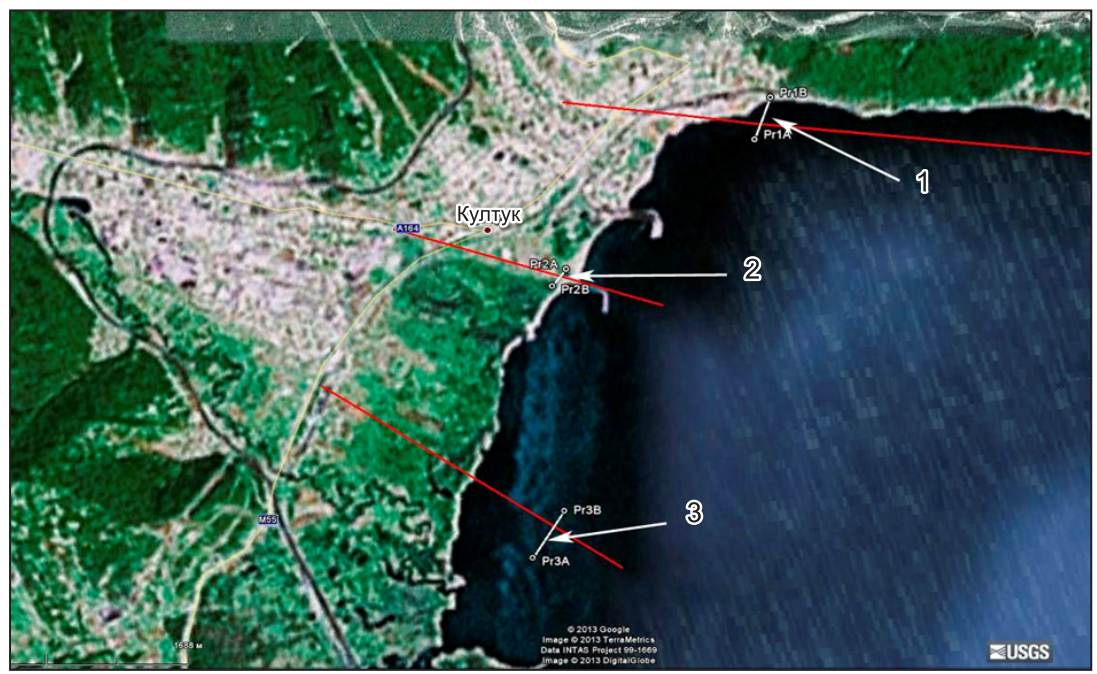

Рис. 10. Схема расположения профилей в районе поселка Култук. Красными линиями отмечены линии разломов земной коры, отрезками белых линий с номерами - профили 1-3, пересекающие разломы.

Fig. 10. Layout of profiles near the Kultuk village. Red lines - crustal faults; segments of white lines with numbers - profiles 1,2 and 3 across the faults.

Рис. 11. Радарограммы профиля 1. Георадар «Око-2»: $(a)$ - АБДЛ «Тритон» $\left(f_{ц}=50\right.$ МГц); (б) АБ-400 $\left(f_{ц}=400\right.$ МГц). Радарограммы приведены к диэлектрической проницаемости воды $\varepsilon_{\text {во- }}$ да $=81$.

Fig. 11. Radarograms of Profile 1. Oko-2 georadar: (a) - ABDL Triton (50 MHz) ); (б) - AB-400 (400 MHz). Radarograms are given to the dielectric constant of water $\varepsilon_{\text {water }}=81$.
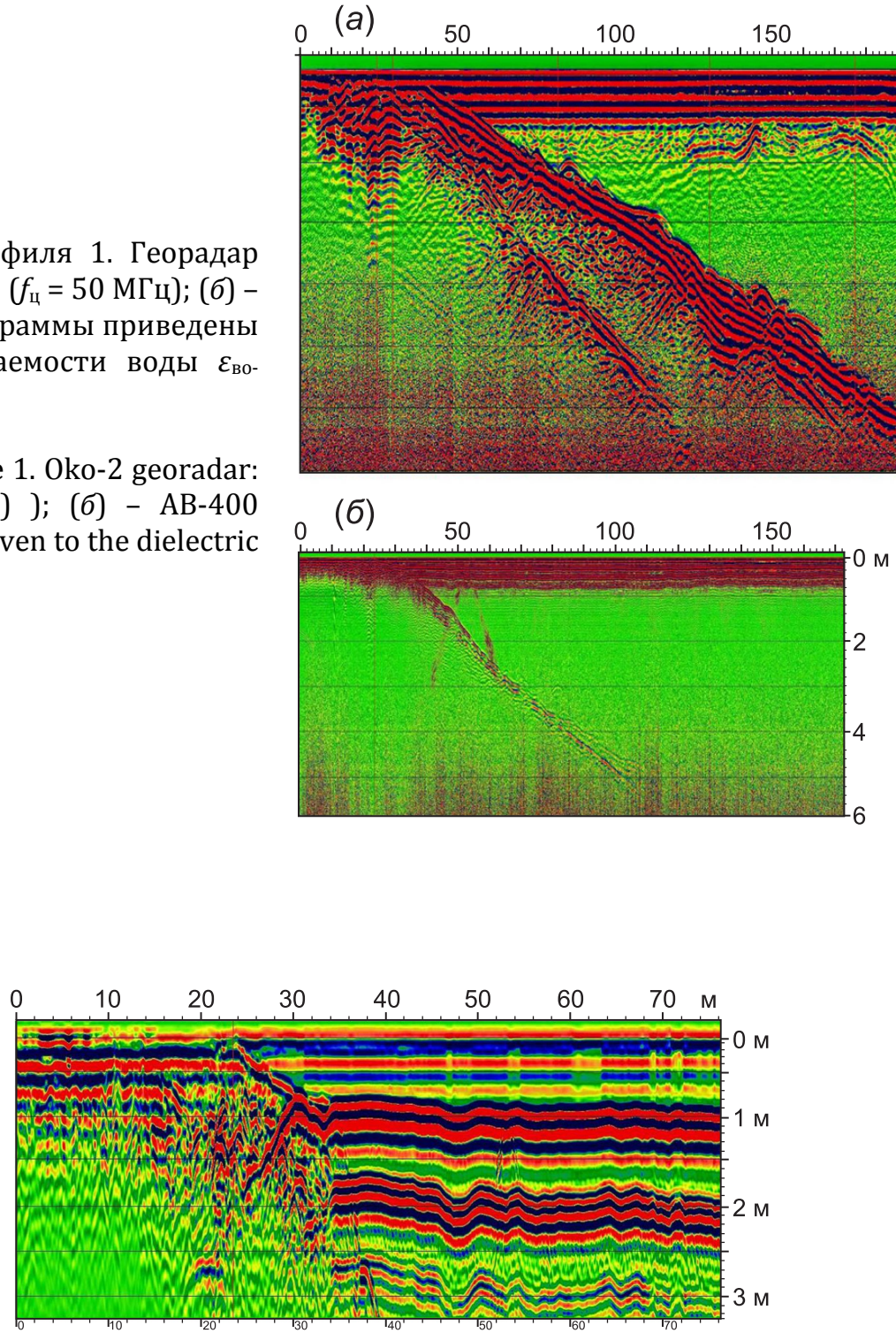

Рис. 12. Радарограмма начала профиля 1. Георадар «Око-2». АБ-400 ( $f_{ц}=400$ МГц). $\varepsilon_{\text {лед }}=3.14$.

Fig. 12. Radarogram of the Profile 1 start. Oko-2 georadar. AB-400 (400 MHz). $\varepsilon_{\text {ice }}=3.14$. 

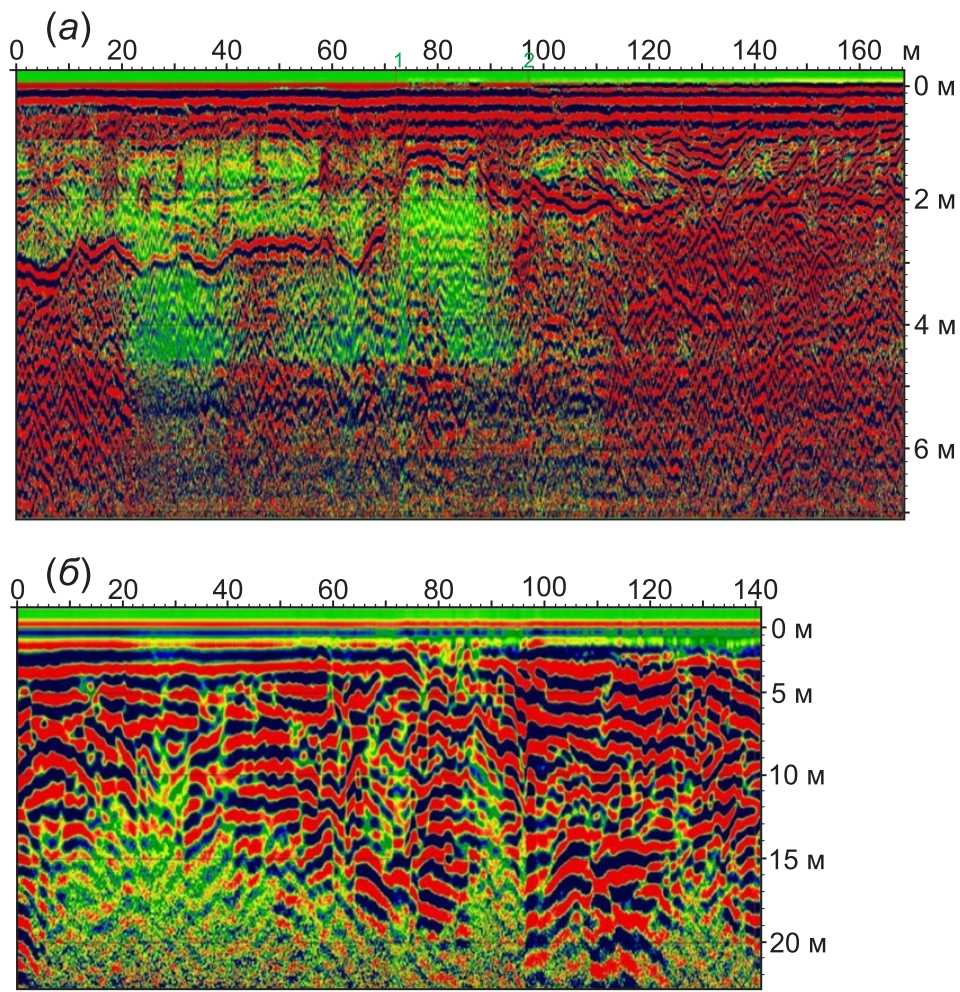

разномасштабная складчатая структура дна прибрежного мелководья (рис. 14, a). Дислокации прослеживаются практически на всем протяжении профиля. Возможно, ширина разломной зоны превышает $350 \mathrm{M}$.

\section{3. ЧЕРЕМШАНСКОЕ МЕСТОРОЖДЕНИЕ КВАРЦИТОВ}

Совместная интерпретация данных радиоимпедансного и георадарного профилирования выявила строение разломной зоны в кристаллических по-

Рис. 14. Радарограммы профиля 3. Георадар «0ко-2»: $(a)-\mathrm{AБ}-400\left(f_{ц}=400\right.$ МГц); (б) - АБДЛ «Тритон» $\left(f_{ц}=50\right.$ МГц).

Fig. 14. Radarogram of Profile 3. Oko-2 georadar: $(a)-$ AB-400 (400 MHz); (б) - ABDL Triton (50 MHz).
Рис. 13. Профиль 2. Георадар «0ко-2»: $(a)-$ АБ- 400 $\left(f_{ц}=400\right.$ МГц $) ;\left(\right.$ б) - АБДЛ «Тритон» $\left(f_{ц}=50\right.$ МГц $)$.

Fig. 13. Profile 2. Okho-2 georadar: $(a)-\mathrm{AB}-400(400$ $\mathrm{MHz}$ ); (б) - ABDL Triton (50 MHz). родах Черемшанского месторождения кварцитов (рис. 15). Разлом имеет ширину 2 м со смещением крыльев по вертикали 2 м. УЭС кварцита в естественном залегании достигает 4000 Ом·м, доломитов - 400 Ом·м. В зонах дробления УЭС пород снижается до 15-50 Ом·м.

\section{4. СЕЙСМОДИСЛОКАЦИИ НА ДНЕ ОЗ. КОТОКЕЛЬ}

В зимне-весеннее время (март - апрель) проведены измерения на пяти профилях в акватории
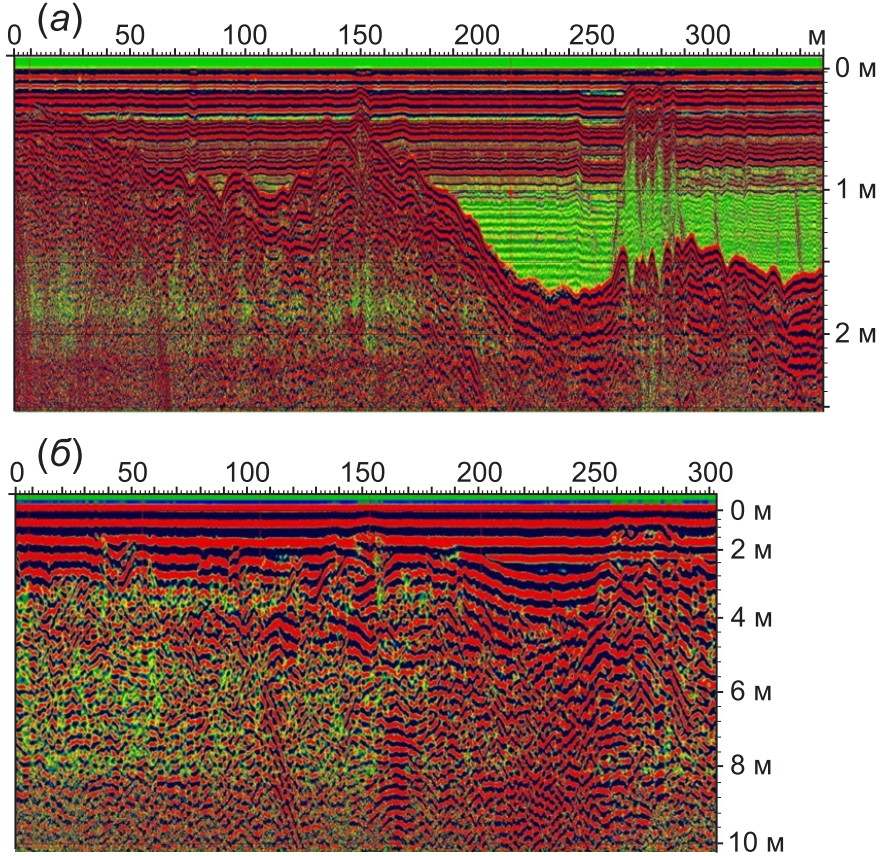



Рис. 15. Черемшанское месторождение кварцитов. (a) - радарограмма зоны тектонического разлома вкрест ее простирания, полученная антенным блоком АБ-700 ( $f_{ц}=700$ МГц); (б) - радарограмма зоны тектонического разлома, полученная антенным блоком АБ-250 ( $f_{ц}=250$ МГц), с нанесенными результатами радиоимпедансного зондирования.

Fig. 15. Cheremshanka quartzite field. (a) - radarogram of the tectonic fault zone across its strike (AB-700 antenna, $700 \mathrm{MHz}$ ); (б) - radarogram of the tectonic fault zone (AB-250 antenna, $250 \mathrm{MHz}$ ); and radioimpedance sounding data.

оз. Котокель методами радиоимпедансного и георадарного зондирования. В качестве примера приведем результаты интерпретации радиоимпедансного зондирования на пикете 7 профиля «Пролив» (рис. 16), на котором по частотной зависимости поверхностного импеданса получен 4-слойный гео- электрический разрез со следующими параметрами:

$$
\begin{array}{lll}
\varepsilon_{1}=3.2, & \rho_{1}=100000 \mathrm{OM}^{\circ} \cdot \mathrm{M}, & h_{1}=0.7 \mathrm{M} ; \\
\varepsilon_{2}=87, & \rho_{2}=160 \mathrm{OM} \cdot \mathrm{M}, & h_{2}=5.2 \mathrm{M} ; \\
\varepsilon_{3}=20, & \rho_{3}=370 \mathrm{OM} \cdot \mathrm{M}, & h_{3}=18 \mathrm{M} ; \\
\varepsilon_{4}=20, & \rho_{4}=3.3 \mathrm{OM} \cdot \mathrm{M}, & h_{4}=\infty .
\end{array}
$$




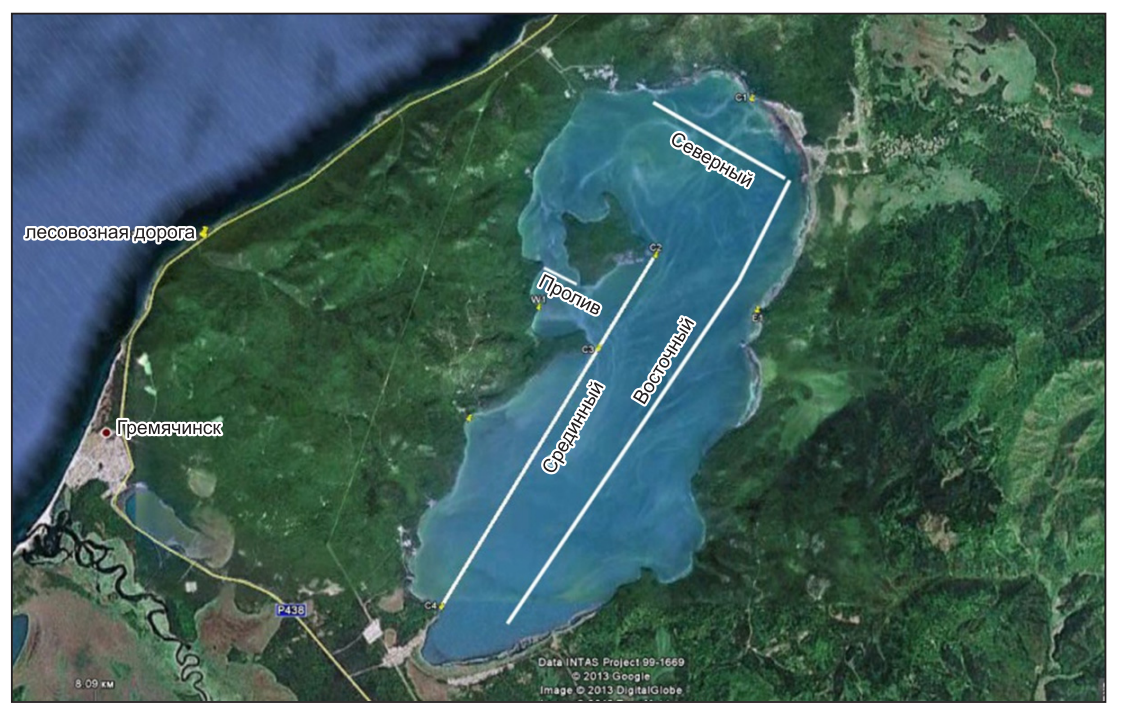

Рис. 16. Схема профилей георадиолокации на оз. Котокель.

Fig. 16. Scheme of GPR profiles on Lake Kotokel.

По результатам радиоимпедансного зондирования на профиле длиной 720 м (18 пикетов) определен ГЭР водной толщи и поддонных отложений на глубину до 50-100 м (рис. 17, б).

Результаты георадарного зондирования по профилю «Пролив» позволили получить данные о тектоническом происхождении котловины озера. На радарограмме профиля «Пролив» присутствуют следы сейсмодислокаций в строении дна пролива (рис. 17, a).

В результате ледовых зимних и летних измерений на оз. Котокель получен большой объем информации, подтверждающей тектоническую природу происхождения его котловины. В качестве примера на рис. 18 представлена радарограмма профиля «Срединный». Рельеф дна озера с излома-
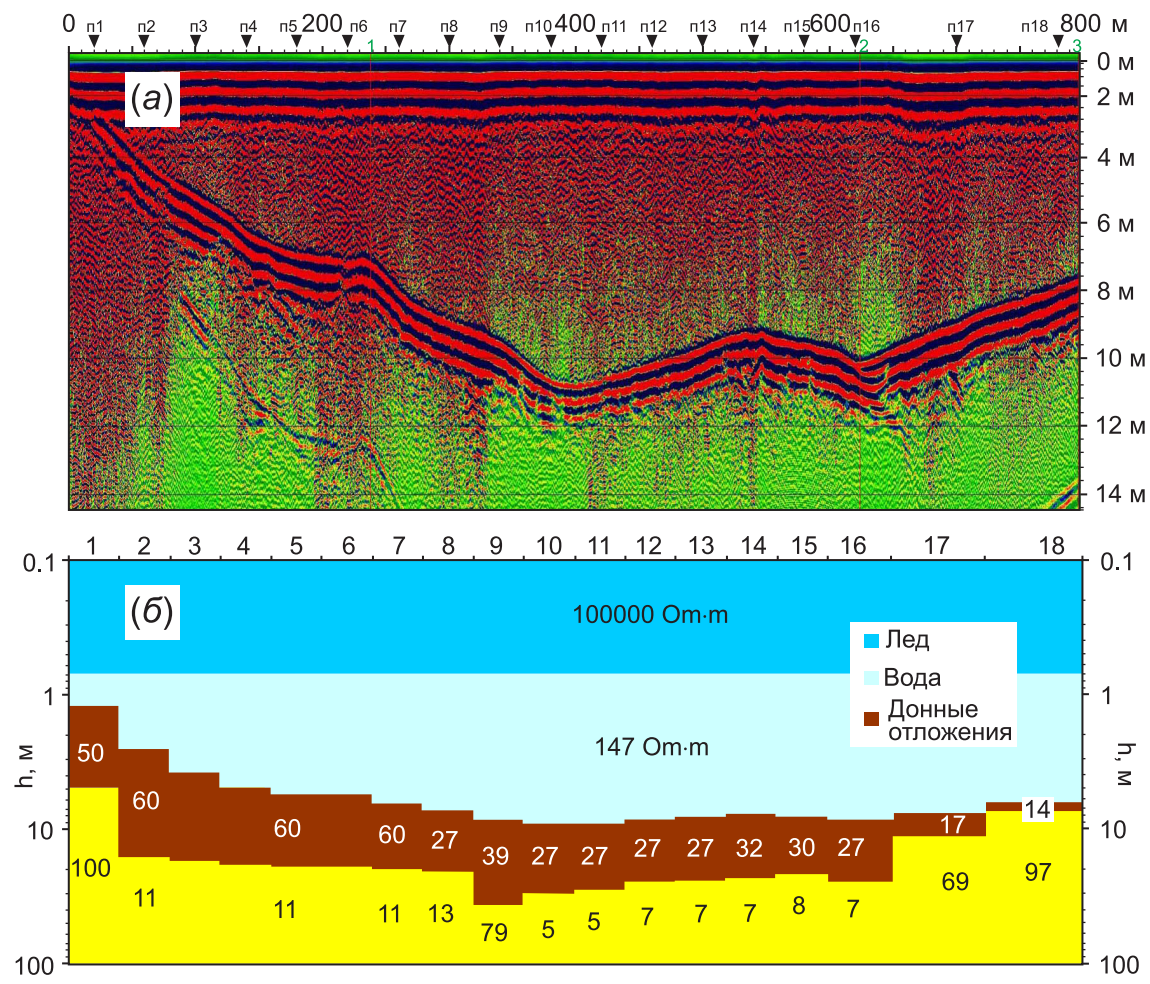

Рис. 17. Профиль «Пролив» на оз. Котокель: $(a)$ - радарограмма. Георадар «Око-2». АБДЛ «Тритон» $\left(f_{ц}=50\right.$ МГц); (б) геоэлектрический разрез. Измеритель поверхностного импеданса ИПИ-300.

Fig. 17. Profile Proliv (Strait), Lake Kotokel: (a) - radarogram. Oko-2 georadar. ABDL Triton (50 MHz); (б) - Geoelectric profile. IPI-300 surface impedance meter. 


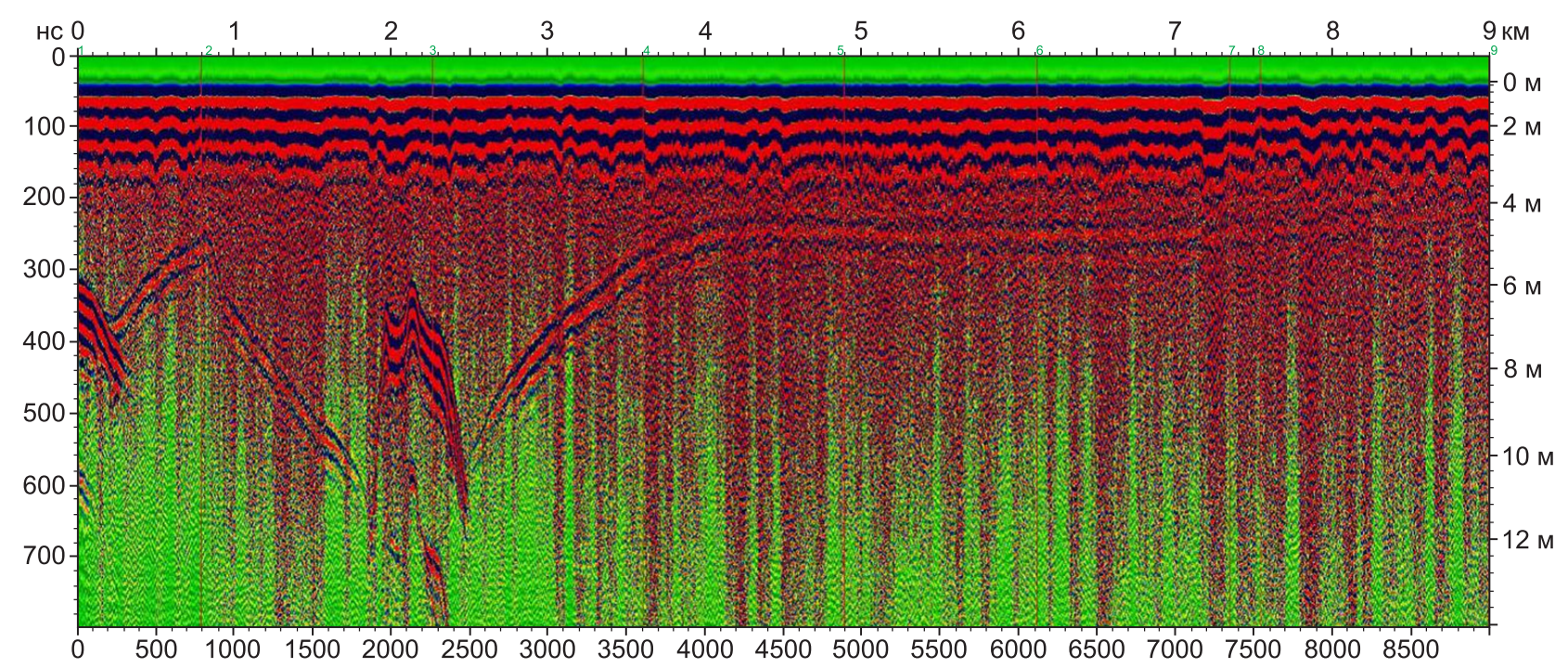

| Рис. 18. Профиль «Срединный» на оз. Котокель. Георадар «Око-2». АБДЛ «Тритон» $\left(f_{ц}=50\right.$ МГц).

Fig. 18. Profile Sredinny (Middle), Lake Kotokel. Oko-2 georadar. ABDL Triton (50 MHz).

ми и выступами на профиле протяженностью 9 км указывает на явно тектонический характер его формирования. Установлена различная отражающая способность дна озера - с приближением к южному концу профиля (правая часть радарограммы) отражающая способность дна на частотах вблизи 50 МГц сильно падает, несмотря на мелководье. На северной стороне профиля на больших глубинах (до 11 м) сигнал от дна заметно выше. Это может быть следствием различной структуры донных отложений. Более рыхлые донные и, соответственно, более пропитанные водой отложения, будут иметь меньшую электромагнитную контрастность для сигнала георадара.
На рис. 19 представлена радарограмма профиля «Северный» (3.7 км), полученная георадаром «Око2» с низкочастотным (наиболее глубинным) антенным блоком АБДЛ «Тритон» $\left(f_{4}=50\right.$ МГц). Желтым пунктиром на рисунке отмечены сейсмодислокации.

Георадарный профиль «Восточный» (рис. 20) выявил разломные зоны 1 и 2 (рис. 20), по которым произошло опускание 6-километрового участка дна озера. Амплитуда опускания может превышать 2 м. На врезке (рис. 20) крупным планом показано строение разломной зоны 1 . На ней отмечены водная толща, донные отложения и линия сейсмодислокации. Кроме того, гиперболические отражения

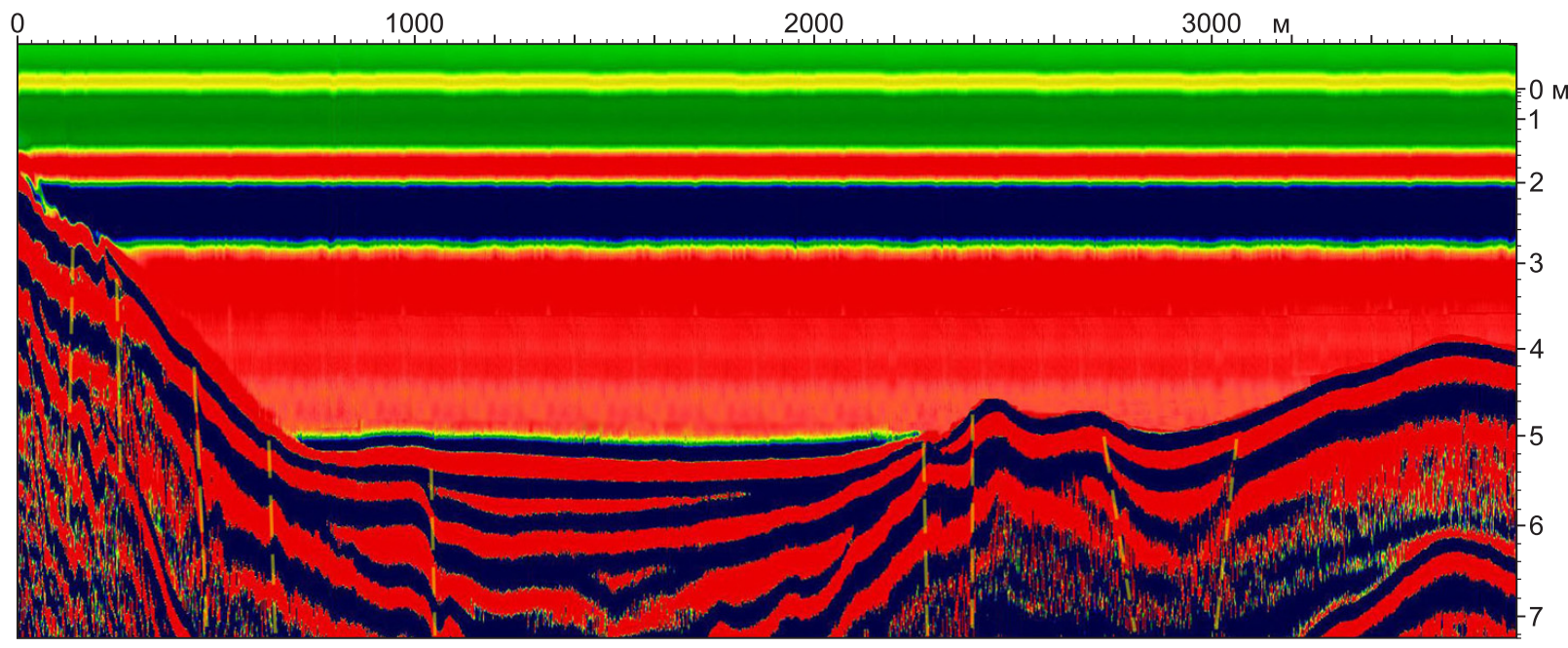

Рис. 19. Профиль «Северный» на оз. Котокель. Георадар «Око-2». АБДЛ «Тритон» $\left(f_{ц}=50\right.$ МГц).

Fig. 19. Profile Severny (Northern), Lake Kotokel. Oko-2 georadar. ABDL Triton (50 MHz). 


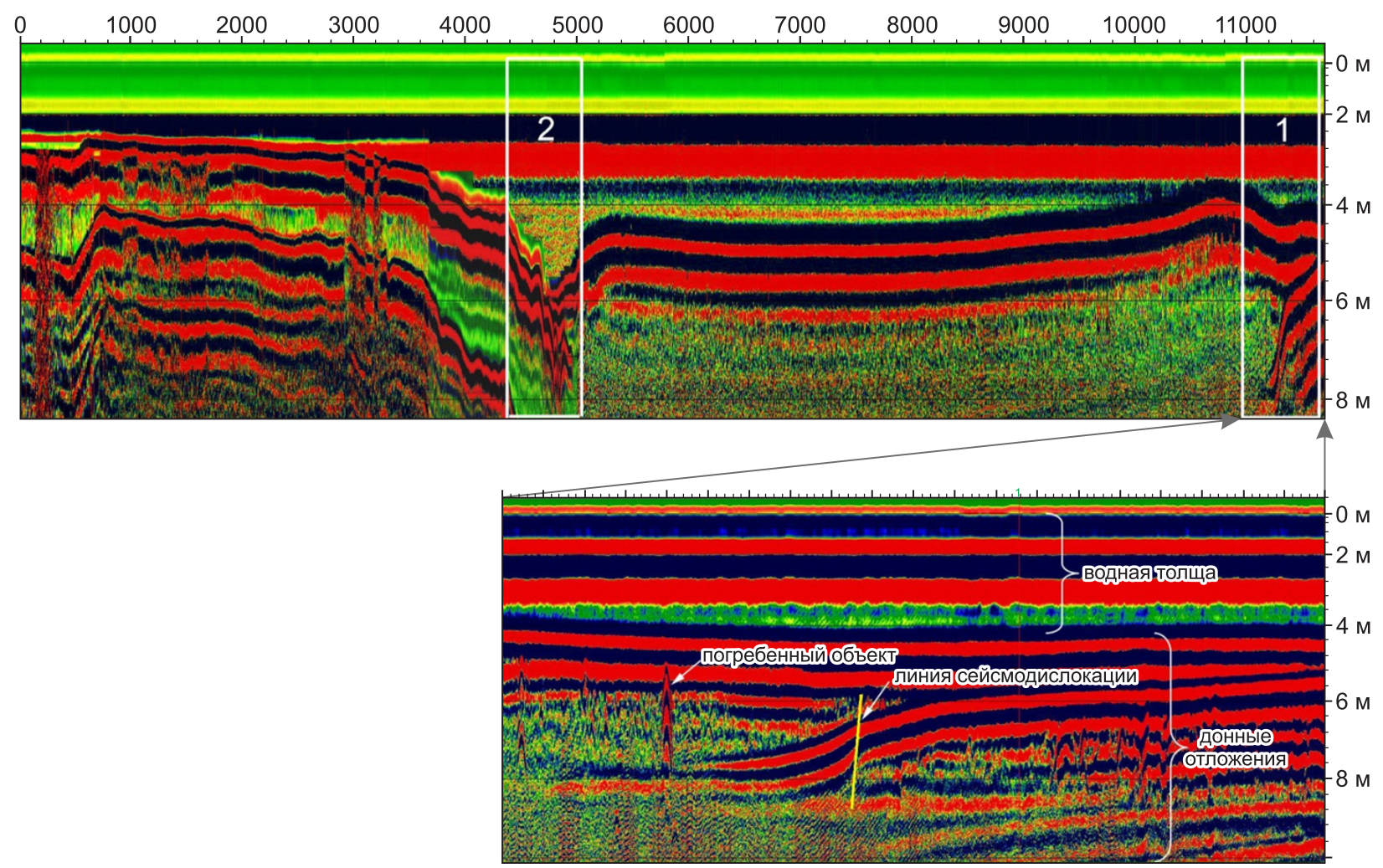

| Рис. 20. Профиль «Восточный» на оз. Котокель. Георадар «Око-2». АБДЛ «Тритон» $\left(f_{ц}=50\right.$ МГц).

| Fig. 20. Profile Vostochny (Eastern), Lake Kotokel. Oko-2 georadar. ABDL Triton (50 MHz).

показывают наличие погребенных объектов в толще донных отложений. Ими могут быть, например, стволы деревьев, оказавшихся на дне во время формирования котловины озера в палеозое.

\section{5. ОБСУЖДЕНИЕ И АНАЛИЗ РЕЗУЛЬТАТОВ}

В результате проведения комплексных радиоволновых измерений и обобщения экспериментальных данных определен геоэлектрический «портрет» массивов горных пород в зонах тектонических нарушений БРЗ. В исследованных районах БРЗ геоэлектрические разрезы горных пород отличаются большим разнообразием за счет наличия сейсмодислокаций в кристаллических горных породах и рыхлых отложениях. Представлены примеры участков развития сейсмодислокаций в массивах горных пород БРЗ, и установлены их электрические свойства. Методика обследования массивов горных пород в зонах тектонических нарушений БРЗ по данным комплексирования радиоволновых измерений в СДВ-ДВ-СВ и УКВ диапазонах и количественная интерпретация слоисто-неоднородной среды позволили получить обобщенные характеристики геоэлектрического строения геологического разреза на глубину до 100 м. Сочетание ра- диолокационного принципа зондирования среды короткими радиоимпульсами [Semeikin et al., 2005; Vladov, Starovoitov, 2004] со спектром в диапазоне 50-1700 МГц, реализованного в георадаре (глубинность 0.1-30.0 м), с методом радиоимпедансного зондирования непрерывными сигналами радиостанций в диапазоне 0.01-1.00 МГц (глубинность до 100-200 м) позволило получить подробную информацию о геоэлектрическом строении приповерхностной части земной коры. Технология бесконтактной радиоинтроскопии горного массива в СДВ-ДВ-СВ и УКВ диапазонах радиоволн повышает производительность малоглубинных зондирований в 3-5 раз по сравнению с методом вертикального электрического зондирования. Полученные результаты и разработанные методики радиоимпедансного и георадарного зондирования и профилирования неоднородной подстилающей среды могут быть использованы при сейсмологических и инженерно-геологических изысканиях в восточных и северных районах России.

\section{6. ЗАКЛЮЧЕНИЕ}

Показана эффективность комплексирования СДВ-ДВ и УКВ электромагнитных методов для ра- 
диоволновой диагностики разломных структур в земной коре в широком диапазоне радиоволн (от десятков килогерц до единиц гигагерц). Радиоимпедансное профилирование и зондирование в СДВДВ диапазонах позволили обнаружить и локализовать разломы в земной коре по изменению импеданса и геоэлектрического разреза. Георадиолокация разломных структур в УКВ диапазоне сделала возможным дифференциацию тонкой структуры тектонического нарушения вплоть до отдельных сейсмодислокаций в осадочных и кристаллических породах и определение кинематики движений в разломной зоне. Использованные методы дополняют друг друга и позволяют объективно и количественно описать объект исследования. Комплексирование различных методов радиоволновой диагностики дает более подробную информацию о структуре зон тектонических нарушений. Резуль- таты исследования электрических свойств зон тектонических нарушений в СДВ-ДВ и УКВ диапазонах радиоволн в целом привели к созданию банка данных [Zherebtsov, 2012] электрических свойств зон тектонических нарушений, учитывающих неоднородно-слоистую структуру земной толщи. Эти данные необходимы при изучении сейсмоактивных районов БРЗ.

\section{7. БЛАГОДАРНОСТИ}

Авторы выражают благодарность В.А. Санькову и А.А. Добрыниной за большую помощь при выборе объектов исследования. Статья подготовлена в ИФМ СО РАН по госбюджетному проекту «Распространение радиоволн в неоднородных импедансных каналах».

\section{8. ЛИТЕРАTУРA / REFERENCES}

Angarkhayeva L.Kh., 2002. Certificate of Official Registration of Computer Program No. 2002610893. Software package "Impedance" for solving problems of radio impedance sensing. ROSPATENT, Moscow, 06.06.2002 (in Russian) [Ангархаева Л.Х. Свидетельство об официальной регистрации программы для ЭВМ № 2002610893. Пакет программ «Импеданс» для решения задач радиоимпедансного зондирования. М.: РОСПАТЕНТ, 06.06.2002].

Bashkuev Yu.B., 1996. Electrical Properties of Natural Layered Media. SB RAS Publishing House, Novosibirsk, 207 p. (in Russian) [Башкуев Ю.Б. Электрические свойства природных слоистых сред. Новосибирск: Изд-во СО РАН, 1996. 207 c.].

Bashkuev Yu.B., Advokatov V.R., Angarkhaeva L.K., 2003. Maps of geoelectric structures of the eastern hemisphere. Izvestiya. Physics of the Solid Earth 39 (9), 778-784.

Bashkuev Yu.B., Khaptanov V.B., 2009. Method and Device for Measuring the Surface Impedance of the Earth's Crust in the ELF range of radio waves. Copyright Certificate No. 299005, 01.08.1989, published 27.12.2009. Inventions. Utility Models. No. 36, SU 1840791 A1 (in Russian) [Башкуев Ю.Б., Хаптанов В.Б. Способ и устройство для измерения поверхностного импеданса земной коры в СНЧ диапазоне радиоволн. Авторское свидетельство № 299005, 01.08.1989 г., опубликовано 27.12.2009. Изобретения. Полезные модели. № 36, SU 1840791 A1].

Efremov V.N., 2013. Radioimpedance Sounding of Frozen Soils. Publishing House of Permafrost Institute SB RAS, Yakutsk, 204 p. (in Russian) [Ефремов В.Н. Радиоимпедансное зондирование мерзлых грунтов. Якутск: Изд-во ИМЗ СО РАН, 2013. 204 с.].

GeoScan32, 2013. Illustrated User Guide. LOGIS, Ramenskoye, 132 p. (in Russian) [GeoScan32. Иллюстрированное руководство пользователя. Раменское: ЛОГИС, 2013. 132 с.].

Melchinov V.P., Bashkuev Yu.B., Angarkhaeva L.Kh., Buyanova D.G., 2006. Electrical Properties of Cryolithic Zone in the Eastern Regions of Russia in the Radio Range. Publishing House of BSC SB RAS, Ulan-Ude, 257 p. (in Russian) [Мельчинов В.П., Башкуев Ю.Б., Ангархаева Л.Х., Буянова Д.Г. Электрические свойства криолитозоны востока России в радиодиапазоне. Улан-Удэ: Изд-во БНЦ СО РАН, 2006. 257 с.].

Radio Engineering Device for Subsurface Sounding (Georadar) Oko-2, 2006. Technical Description. Manual. Version 2.6.2009. Logicheskie Sistemy LLC, Moscow, 101 p. (in Russian) [Радиотехнический прибор подповерхностного зондирования (георадар) «Око-2». Техническое описание. Инструкция по эксплуатации. Версия 2.6.2009. М.: 000 «Логические Системы», 2006. 101 c.]. Available from: http://www.logsys.ru/.

Semeikin N.P., Pomozov V.V., Dudnik A.V., 2005. Development of OKO georadars. In: A.Yu. Grinev (Ed.), Problems of subsurface radiolocation. Radiotekhnika, Moscow, p. 231-236 (in Russian) [Семейкин Н.П., Помозов В.В., Дудник А.В. Развитие георадаров серии «ОКО» // Вопросы подповерхностной радиолокации / Ред. А.Ю. Гринев. М.: Радиотехника, 2005. С. 231-236].

Smekalin O.P., 2008. Study of Paleoseismogenic Deformations of the Southern Pribaikalie. IPE RAS, Moscow, 101 p. (in Russian) [Смекалин О.П. Изучение палеосейсмогенных деформаций Южного Прибайкалья. М.: ИФЗ РАН, 2008. 101 c.].

Tezkan B., Saraev A., 2008. A new broadband radiomagnetotelluric instrument: applications to near surface investigations. Near Surface Geophysics 6 (4), 245-252. https://doi.org/10.3997/1873-0604.2008019.

Velikhov E.P. (Ed.), 2014. Interaction of Electromagnetic Fields of the Controlled Sources of the ELF range with the Ionosphere and the Earth's Crust. Materials of the All-Russia (with international participation) seminar. Vol. 1. 
Yu.B. Bashkuev et al.: Integration of the GPR and radio-impedance techniques...

Geological Institute KSC RAS, Apatity, 206 p. (in Russian) [Взаимодействие электромагнитных полей контролируемых источников СНЧ-диапазона с ионосферой и земной корой: Материалы Всероссийского (с международным участием) научно-практического семинара. Т. 1 / Ред. Е.П. Велихов. Апатиты: Геологический институт КНЦ РАН, 2014. 206 с.].

Velikhov E.P. (Ed.), 2015. Interaction of Electromagnetic Fields of the ELF-ULF range with the Ionosphere and the Earth's Crust. Materials of the 1st All-Russia (with international participation) seminar. Vol. 2. Geological Institute KSC RAS, Apatity, 112 p. (in Russian) [Взаимодействие электромагнитных полей КНЧ-СНЧ диапазона с ионосферой и земной корой: Материалы I Всероссийского (с международным участием) научно-практического семинара. Т. 2 / Ред. Е.П. Велихов. Апатиты: Геологический институт КНЦ РАН, 2015. 112 с.].

Velikhov E.P., Zhamaletdinov A.A., Shevtsov A.N., Tokarev A.D., Kononov Y.M., Pesin L.B., Kadyshevich G.M., Pertel' M.I., Veshchev A.V., 1998. Deep electromagnetic studies with the use of powerful ELF radio installations. Izvestiya, Physics of the Solid Earth 34 (8), 615-632.

Vladov M.L., Starovoitov A.V., 2004. Introduction to GPR. MSU Publishing House, Moscow, 153 p. (in Russian) [Влaдов М.Л., Старовойтов А.В. Введение в георадиолокацию. М.: Изд-во МГУ, 2004. 153 с.].

Zherebtsov G.A. (Ed.), 2012. Seismic Ionospheric and Seismic Electromagnetic Processes in the Baikal Rift Zone. SB RAS Publishing House, Novosibirsk, 304 p. (in Russian] [Сейсмоионосферные и сейсмоэлектромагнитные процессы в Байкальской рифтовой зоне / Ред. Г.А. Жеребцов. Новосибирск: Изд-во СО РАН, 2012. 304 с.].

\section{Юрий Буддич Башкуев}

докт. техн. наук, профессор, зав. лабораторией

Институт физического материаловедения СО РАН

670047, Улан-У дэ, ул. Сахьяновой, 6, Россия

凶e-mail: buddich@mail.ru

(iD) https://orcid.org/0000-0002-7102-3977

\section{Валерий Бажеевич Хаптанов}

канд. физ.-мат. наук, с.н.с.

Институт физического материаловедения СО РАН

670047, Улан-Удэ, ул. Сахьяновой, 6, Россия

e-mail:vkhaptanov@mail.ru

(iD) https://orcid.org/0000-0001-7113-1655

\section{Михаил Георгиевич Дембелов}

канд. физ.-мат. наук, с.н.с.

Институт физического материаловедения СО РАН

670047, Улан-Удэ, ул. Сахьяновой, 6, Россия

e-mail: mdembelov@mail.ru

(iD) https://orcid.org/0000-0002-7281-4252

\section{Yuri B. Bashkuev}

Doctor of Technical Sciences, Professor, Head of Laboratory

Institute of Physical Materials Science, Siberian Branch of RAS

6 Sakhyanova street, Ulan-Ude 670047, Russia

\section{Valery B. Khaptanov}

Candidate of Physics and Mathematics, Senior Researcher

Institute of Physical Materials Science, Siberian Branch of RAS 6 Sakhyanova street, Ulan-Ude 670047, Russia

\section{Mikhail G. Dembelov}

Candidate of Physics and Mathematics, Senior Researcher

Institute of Physical Materials Science, Siberian Branch of RAS 6 Sakhyanova street, Ulan-Ude 670047, Russia 